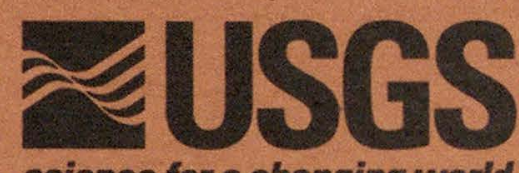

science for a changing world

\title{
Hydrology and Ground-Water Quality in Glacial Deposits in the Nepaug Reservoir Watershed, Northwestern Connecticut, 1998-2000
}

Open-File Report 03-350

In cooperation with the Metropolitan District Commission

U.S. Department of the Interior

U.S. Geological Survey 
U.S. Department of the Interior

U.S. Geological Survey

\section{Hydrology and Ground-Water Quality in} Glacial Deposits in the Nepaug Reservoir Watershed, Northwestern Connecticut, 1998-2000

By Remo A. Mondazzi and J. Jeffrey Starn

Open-File Report 03-350

In cooperation with the Metropolitan District Commission 


\title{
U.S. DEPARTMENT OF THE INTERIOR \\ GALE A. NORTON, Secretary
}

\author{
U.S. GEOLOGICAL SURVEY
}

Charles G. Groat, Director

The use of firm, trade, and brand names in this report is for identification purposes

only and does not constitute endorsement by the U.S. Geological Survey.

For additional information write to:

\section{District Chief}

U.S. Geological Survey

101 Pitkin Street

East Hartford, CT 06108

ct.water.usgs.gov
Copies of this report can be purchased from:

U.S. Geological Survey

Branch of Information Services

Box 25286, Federal Center

Denver, CO 80225 


\section{CONTENTS}

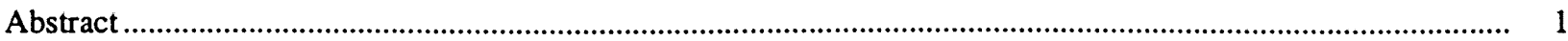

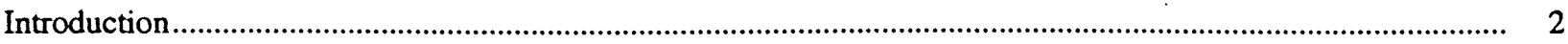

Purpose and Scope

Previous Investigations................................................................................................................... 2

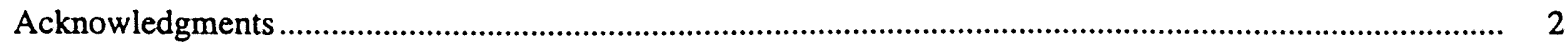

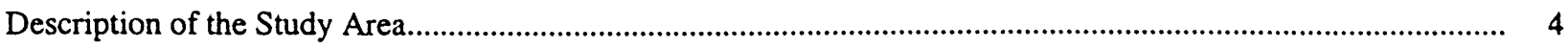

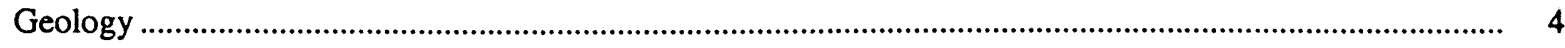

Hydrologic Conditions ......................................................................................................................... 4

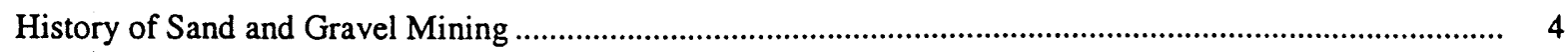

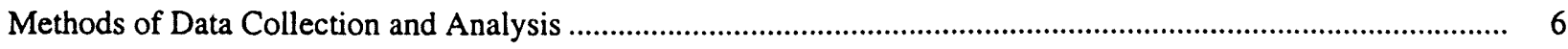

Test-Hole Drilling and Monitoring-Well Installation ............................................................................... 6

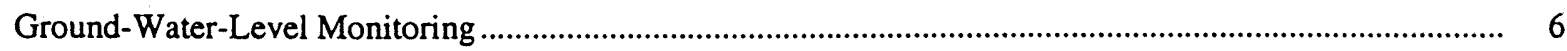

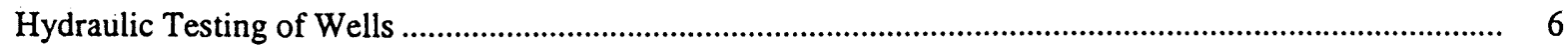

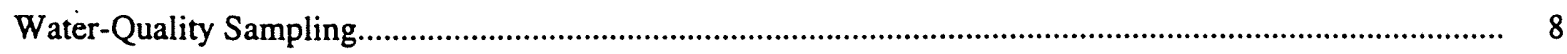

Hydrology of Glacial Deposits in the Nepaug Reservoir Watershed ................................................................ 8

Ground-Water Levels .......................................................................................................................... 9

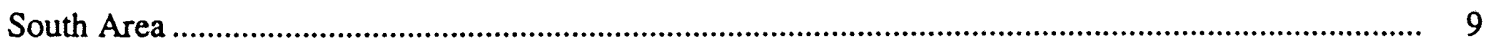

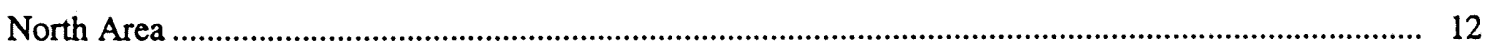

Hydraulic Properties:........................................................................................................................ 16

Interaction Between Ground Water and Surface Water .................................................................... 17

Hydrologic Importance of the Glacial Deposits.................................................................................... 19

Ground-Water Quality in Glacial Deposits in the Nepaug Reservoir Watershed.................................................... 19

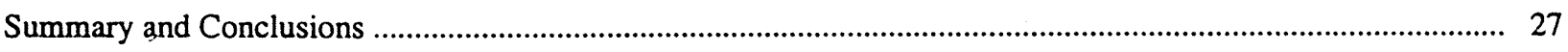

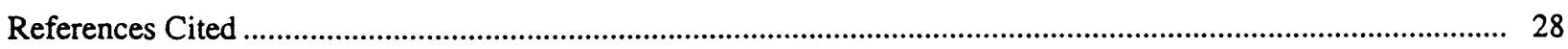

Figures

1. Map showing location of the Nepaug Reservoir watershed and the North and South Areas, northwestern Connecticut.

2. Maps showing location of roads, wells, test holes, and selected sand and gravel deposits in

(A) the South Area and (B) the North Area, Nepaug Reservoir watershed, northwestern Connecticut.

3. Graphs showing water-level fluctuations in Clear Brook wells (BU-127D, BU-128S, BU-129D, BU-130S, BU-131D, BU-132S, and BU-142; South Area) compared to streamflow in Clear Brook and daily precipitation at Burlington, northwestern Connecticut, September 1998 to December 2000 ... 11

4. Graphs showing water-level fluctuations in Phelps Brook wells (BU-133S, BU-134D, BU-136D, BU-137S, BU-138D, BU-139S, BU-140D and BU-141S; South Area), compared to streamflow in Phelps Brook and daily precipitation at Burlington, northwestern Connecticut, September 1998 to December 2000.

5. Graphs showing differences in timing of highest water levels and thickness of unsaturated deposits in wells BU-127D, BU-129D, BU-131D, and BU-140D (South Area), Nepaug Reservoir watershed, northwestern Connecticut, September 1998 to December 2000 


\section{Figures-Continued}

6. Graphs showing water-level fluctuations in the Nepaug River wells (NH-135 to NH-139; North Area), compared to streamflow in Nepaug River and daily precipitation at Burlington, northwestern Connecticut, September 1998 to December 2000

7. Graphs showing differences in timing of highest water-levels and thickness of unsaturated deposits in wells NH-135, NH-138, and NH-139 (North Area), Nepaug Reservoir watershed, northwestern Connecticut, September 1998 to December 2000

8. Graphs showing difference in median winter streamflow (January through March), and median summer streamflow (July through September), Burlington Brook, Clear Brook, and Nepaug River,

Nepaug Reservoir watershed, northwestern Connecticut.

9. Graphs showing analysis of ion concentration represented by patterns based on milliequivalents per liter in ground-water samples, Nepaug Reservoir watershed, northwestern Connecticut, May 1999 ...... 25

10. Graphs showing analysis of ion concentration represented by patterns based on milliequivalents per liter in ground-water samples, Nepaug Reservoir watershed, northwestern Connecticut, August through September 1999.

\section{Tables}

1. Selected construction and lithologic data for monitoring wells and test holes in the Nepaug Reservoir watershed, northwestern Connecticut.

2. Range of water levels in wells and unsaturated and saturated thicknesses of glacial deposits, Nepaug Reservoir watershed, northwestern Connecticut

3. Calculated hydraulic conductivity values from slug tests in monitoring wells, Nepaug Reservoir watershed, northwestern Connecticut

4. Field measurements and concentrations of nutrients and organic carbon in ground-water samples, Nepaug Reservoir watershed, northwestern Connecticut, May 1999 and August through October 199920

5. Concentrations of major inorganic compounds and dissolved solids in ground-water samples, Nepaug Reservoir watershed, northwestern Connecticut, May 1999 and August through October 199922

\section{CONVERSION FACTORS, DATUMS, AND ABBREVIATIED WATER-QUALITY UNITS}

\begin{tabular}{rll}
\hline Multiply & \multicolumn{1}{c}{ By } & To obtain \\
\hline inch (in) & 2.54 & centimeter \\
foot $(\mathrm{ft})$ & 0.3048 & meter \\
square mile $\left(\mathrm{mi}^{2}\right)$ & 2.590 & square kilometer \\
cubic yard $\left(\mathrm{yd}^{3}\right)$ & 0.7645 & cubic meter \\
cubic foot per second $\left(\mathrm{ft}^{3} / \mathrm{s}\right)$ & 0.02832 & cubic meter per second \\
pound per square inch $\left(\mathrm{lb} / \mathrm{in}^{2}\right)$ & 51.71 & millimeters of mercury \\
foot per day $(\mathrm{ft} / \mathrm{d})$ & 0.3048 & meter per day \\
\hline
\end{tabular}

Temperature in degrees Celsius $\left({ }^{\circ} \mathrm{C}\right)$ may be converted to degrees Fahrenheit $\left({ }^{\circ} \mathrm{F}\right)$ as follows: ${ }^{\circ} \mathrm{F}=\left(1.8 \times{ }^{\circ} \mathrm{C}\right)+32$

Temperature in degrees Fahrenheit $\left({ }^{\circ} \mathrm{F}\right)$ may be converted to degrees Celsius $\left({ }^{\circ} \mathrm{C}\right)$ as follows: ${ }^{\circ} \mathrm{C}=\left({ }^{\circ} \mathrm{F}-32\right) / 1.8$

Specific conductance is given in microsiemens per centimeter at 25 degrees Celsius $\left(\mu \mathrm{S} / \mathrm{cm}\right.$ at $\left.25^{\circ} \mathrm{C}\right)$.

Concentration of chemical constituents is given in milligrams per liter $(\mathrm{mg} / \mathrm{L})$ or micrograms per liter $(\mu \mathrm{g} / \mathrm{L})$.

Hydraulic conductivity: The standard unit for hydraulic conductivity is cubic foot per day per square foot of aquifer cross-sectional area $\left(\mathrm{ft}^{3} / \mathrm{d}\right) \mathrm{ft}^{3}$. In this report, the mathematically reduced form, foot per day $(\mathrm{ft} / \mathrm{d})$, is used for convenience.

Vertical coordinate information is referenced to the North American Vertical Datum of 1988 (NAVD 88); horizontal coordinate information is referenced to the North American Datum of 1927 (NAD 27). 


\title{
Hydrology and Ground-Water Quality in Glacial Deposits in the Nepaug Reservoir Watershed, Northwestern Connecticut, 1998-2000
}

\author{
by Remo A. Mondazzi and J. Jeffrey Starn
}

\begin{abstract}
Ground-water investigations were conducted in stratified glacial deposits in the Nepaug Reservoir watershed in northwestern Connecticut to assess the effects of sand and gravel mining on the hydrology of the watershed. In an ongoing investigation between the U.S. Geological Survey and the Metropolitan District Commission (in Connecticut), hydrologic and ground-water quality data were collected in two areas of thick unconsolidated sand and gravel deposits in the watershed-referred to as the South Area and the North Area.
\end{abstract}

Ground-water levels were measured to determine ground-water-flow directions, hydraulic gradients, and ground-water storage at well locations in the two areas. Ground-waterlevel fluctuations during the study period (19982000) ranged from 1.1 to 9.9 feet (ft). Observed fluctuations in water levels were similar to typical seasonal fluctuations in Connecticut, but the timing of the fluctuations between the North and South Areas differed. Water levels in wells in the South Area responded immediately to the intense precipitation from Tropical Storm Floyd in September 1999 (about 8.5 inches (in.) of rain over 2 days), whereas water levels in wells in the North Area did not show an abrupt rise. Hydraulic (slug) tests were conducted in seven monitoring wells to determine horizontal hydraulic conductivities of the glacial deposits; conductivity values ranged from 0.93 to 16.7 feet per day (ft/d) and from 1.4 to $23.5 \mathrm{ft} / \mathrm{d}$ using two methods of analysis.
In addition to hydrologic measurements, ground-water samples also were collected from selected wells during two seasons-spring, when most annual recharge typically occurs and groundwater levels are high; and late summer, when ground-water levels are typically low. Water temperature was consistently higher in the late summer samples than in the spring samples in all wells. Dissolved oxygen concentrations were consistently higher in the spring samples, sulfate concentrations were lower in the summer samples, and silica concentrations were lower in the spring samples in all wells. The $\mathrm{pH}$ values ranged from 5.7 to 6.1 standard units in water from wells in a recharge zone and from 6.0 to 7.0 standard units in water from wells in a discharge zone.

Although the information presented in this report is not definitive with regard to the effects of mining the glacial deposits in this area, the data collected support two concepts: (1) that thick coarse-grained deposits of sand and gravel have the capacity to store rainfall and release that water slowly to streams, thus decreasing high streamflows and increasing low streamflows; and (2) that peaks in ground-water levels related to seasonal fluctuations occur later (in the year) with increasing thicknesses of coarse-grained unsaturated deposits. If mining reduces the thickness of the sand and gravel deposits, the hydrologic characteristics of a mined area will be similar to areas of thin, but unmined, sand and gravel deposits. A potential consequence of mining may be increased streamflow following precipitation events and decreased summer streamflow. 


\section{INTRODUCTION}

The Nepaug Reservoir, in northwestern Connecticut, provides water to the city of Hartford and surrounding communities. The Metropolitan District Commission (MDC) monitors and manages land use in the Nepaug Reservoir watershed to provide highquality water for drinking and other municipal uses. Activities in the watershed that may affect water quality include sand and gravel mining, increased public access, increased residential and commercial development, and changes in forestry practices. Sand and gravel deposits have been mapped throughout the Nepaug Reservoir watershed (Stone and others, 1992). Sand and gravel mining, including the removal of overlying soils and vegetation, may affect water quality in and near the reservoir because unsaturated sand and gravel deposits store water from precipitation events and (or) buffer chemical reactions. Removing these deposits could ultimately affect water quality in the reservoir.

In 1997, the U.S. Geological Survey (USGS) and the MDC began a cooperative three-phase study to evaluate potential effects of sand and gravel mining on streamflow and the quality of water entering the reservoir. The first phase of the study was designed to determine the hydrogeologic framework of the sand and gravel deposits; the results were published by Stone and others (2001). The hydrogeology of sand and gravel deposits in two areas adjacent to the Nepaug Reservoir was described, including information on the distribution of stratified glacial deposits (gravel, sand, silt, and clay); the thickness and volumes of these materials; the altitude of the water table; the altitude of the bedrock surface; and the potential effects of sand and gravel mining on the physical and chemical responses of the watershed. For convenience in estimating the volumes of sand and gravel in phase 1, two areas of thick sand and gravel deposits in the watershed were delineated; these are referred to as the South Area and the North Area, because of their geographic relation to each other (fig. 1). Phase 2 of the study involved additional data collection and interpretation of groundwater level and ground-water-quality data; those results are presented in this report. Phase 3 of the study will focus on surface-water quality, including estimates of nutrient loads to the Nepaug Reservoir from the watershed. An understanding of nutrient and other constituent loads will help MDC establish a sound scientific relation between land use and potential water-quality changes.

\section{Purpose and Scope}

This report summarizes hydrologic and groundwater-quality data collected in areas adjacent to the Nepaug Reservoir from September 1998 to December 2000. It includes ground-water-level measurements in 21 wells, results of hydraulic tests in 7 monitoring wells, and water-quality analyses of two seasonal rounds of ground-water samples (May and AugustSeptember) in 11 wells. The locational terminology established in phase 1-the South Area and the North Area-are used in this report.

\section{Previous Investigations}

Stone and others (2001) described and mapped the hydrogeology of the Nepaug Reservoir watershed, and focused on two areas of thick sand and gravel deposits in the watershed-the North Area and the South Area (fig. 1). Information was compiled on the altitude of the bedrock surface, altitude of the water table, general ground-water-flow directions, and on the distribution, thickness, and volumes of sand and gravel deposits in the North and South areas. Stone and others (1992) also mapped the geology of the Nepaug Reservoir watershed as part of a statewide investigation. Handman and others (1986) investigated the hydrogeology of the Nepaug Reservoir watershed as part of a study of the Farmington River Basin and compiled information on the distribution of sand and gravel aquifers, the hydraulic properties of unconsolidated materials, the altitude of bedrock in the valleys, and streamflow characteristics.

\section{Acknowledgments}

The authors would like to thank Leland Sanders of the MDC for his assistance during this study. In addition, the authors also thank the following USGS employees: Jonathan Morrison, Rylan Farr, and Staunton Williams, Jr. for assistance during the groundwater-data collection; John Mullaney and Gardner Bent for technical reviews, and Barbara Korzendorfer for preparation of this report. 


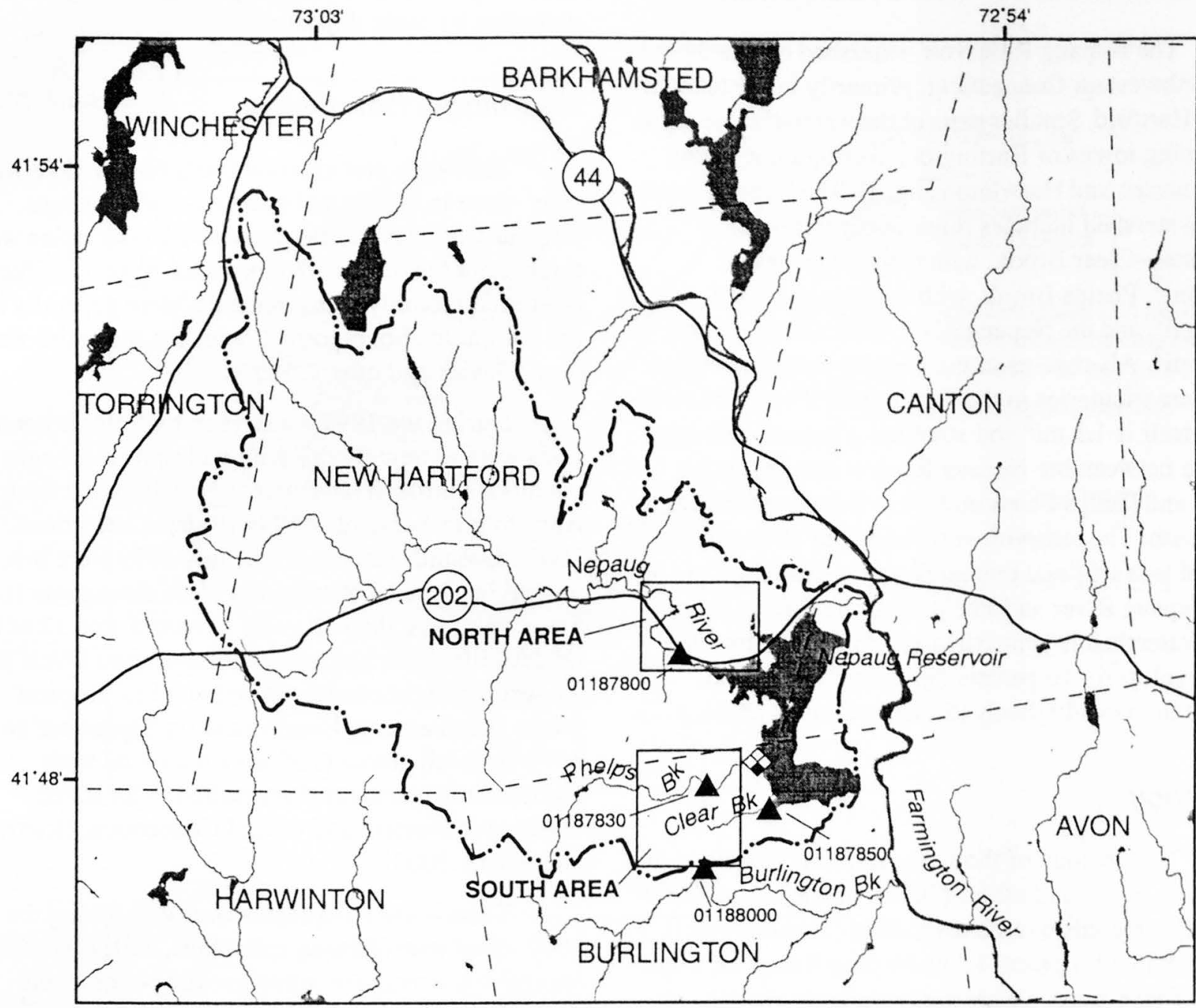

Base from U.S. Geological Survey

digital line graphs (1980 and 1988)
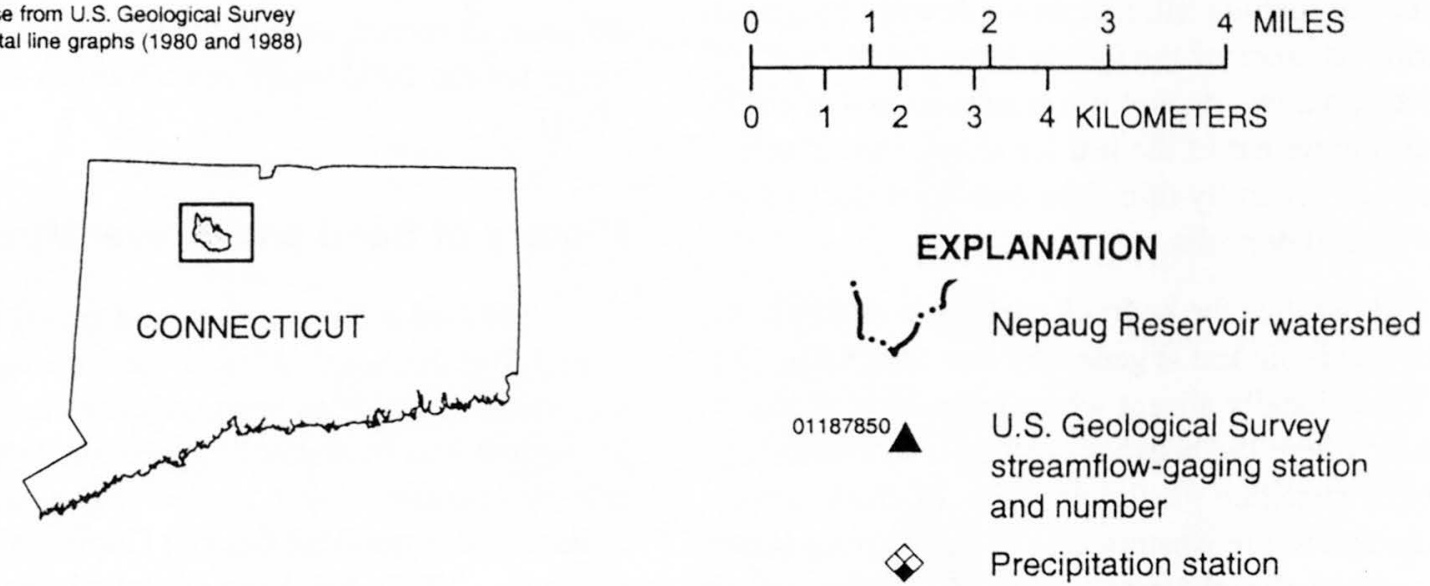

Figure 1. Location of the Nepaug Reservoir watershed and the North and South Areas, northwestern Connecticut. 


\section{DESCRIPTION OF THE STUDY AREA}

The Nepaug Reservoir watershed covers $32 \mathrm{mi}^{2}$ in northwestern Connecticut, primarily in the town of New Hartford. Smaller parts of the watershed are in the adjoining towns of Burlington, Torrington, Canton, Winchester, and Harwinton (fig. 1). The Nepaug Reservoir watershed includes three easterly flowing streams-Clear Brook, with a drainage area of $0.56 \mathrm{mi}^{2}$, Phelps Brook, with a drainage area of $3.04 \mathrm{mi}^{2}$, and the Nepaug River, with a drainage area of $23.4 \mathrm{mi}^{2}$. All streams in the Nepaug Reservoir watershed are tributaries to the Farmington River. The reservoir itself is $1.3 \mathrm{mi}^{2}$ and straddles a former drainage divide between the Nepaug River watershed to the north and Phelps Brook and Clear Brook watersheds to the south. The reservoir was formed by the construction of two artificial impoundments-Nepaug Dam on the Nepaug River and Phelps Dam on Phelps Brook. The watershed is approximately 86 percent forested (undeveloped), 10 percent agricultural land, and 2 percent roads/highway (Stone and others, 2001, p. 2).

\section{Geology}

The geology of the study area was described in detail by Stone and others (2001). Surficial (unconsolidated) materials overlie crystalline (metamorphic) bedrock in most places in the Nepaug Reservoir watershed. These materials are predominantly glacial deposits that include till, laid down directly by glacial ice during advance of the ice sheet, and stratified deposits, laid down by meltwater streams and in glacial lakes during retreat of the last ice sheet. Post-glacial deposits are generally thin (less than $10 \mathrm{ft}$ thick) and overlie glacial deposits.

Till overlies the bedrock surface in most places near the reservoir and is generally less than 10 to $15 \mathrm{ft}$ thick. Till is locally absent where bedrock is at land surface or where the bedrock surface is overlain directly by stratified glacial deposits. In much of the area adjacent to the western side of the Nepaug Reservoir, stratified glacial deposits up to $250 \mathrm{ft}$ thick overlie till and (or) bedrock. These deposits consist of coarsegrained sediments (gravel, sand and gravel, and sand) and fine-grained sediments (very fine sand, silt, and clay). Large areas of Phelps Brook and Clear Brook drainage basins are underlain by coarse-grained glacial deposits ( 52 percent and 45 percent, respectively).
Only 13 percent of the Nepaug River drainage basin is underlain by these deposits.

\section{Hydrologic Conditions}

Statewide precipitation totals for the 1998 water year $^{1}$ were in the normal to above-normal range. Ground-water levels, measured in 14 observation wells throughout the State with more than 30 years of record of at least monthly measurements, were generally in the normal to above-normal range for the entire water year (Davies and others, 1999).

During the 1999 water year, hydrologic conditions were extremely dry with widespread drought conditions throughout much of New England from April to mid-September 1999 (Ranzau and others, 2000). Ground-water levels in July 1999 were below normal in 11 of 14 observation wells throughout the State with more than 30 years of record, and 12 of the observation wells had below-normal water levels in August. Drought conditions ended when Tropical Storm Floyd entered Connecticut on September 16, 1999. Rainfall amounts of more than 9 in. were reported in some areas that resulted in localized flooding in western and central Connecticut (Ranzau and others, 2000).

There were no droughts or floods during the 2000 water year (Ranzau and others, 2001). With few exceptions, average monthly ground-water levels measured in 14 observation wells with more than 30 years of record were in the normal or above-normal range for the 2000 water year (Ranzau and others, 2001).

\section{History of Sand and Gravel Mining}

Limited mining of sand and gravel from deposits $A$ and B in the South Area of the Nepaug Reservoir watershed (fig. 2) has been ongoing since 1971. Deposit B was mined until approximately 1974 , when mining operations were moved to Deposit A (Leland Sanders, Metropolitan District Commission, oral commun., 2002). Sand and gravel mining of Deposit A continued throughout the study period.

\footnotetext{
${ }^{1} \mathrm{~A}$ water year is the 12 -month period from October 1 through September 30 and is designated by the calendar year in which it ends. For example, the year beginning October 1, 1997 and ending September 30, 1998, is called the 1998 water year.
} 

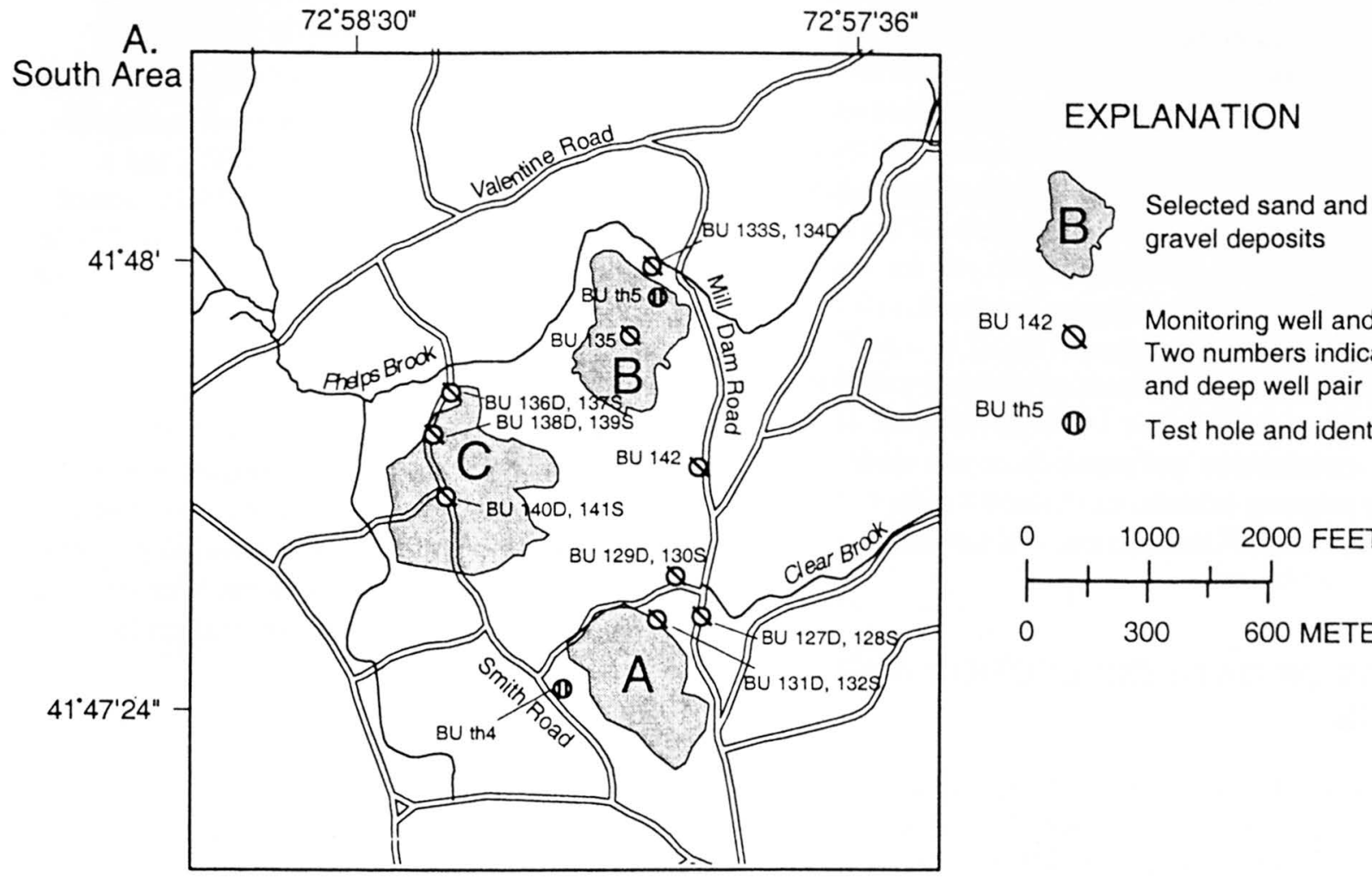
BU $142 Q \quad$ Monitoring well and identifier-- Two numbers indicate shallow and deep well pair

BU th5 (1) Test hole and identifier
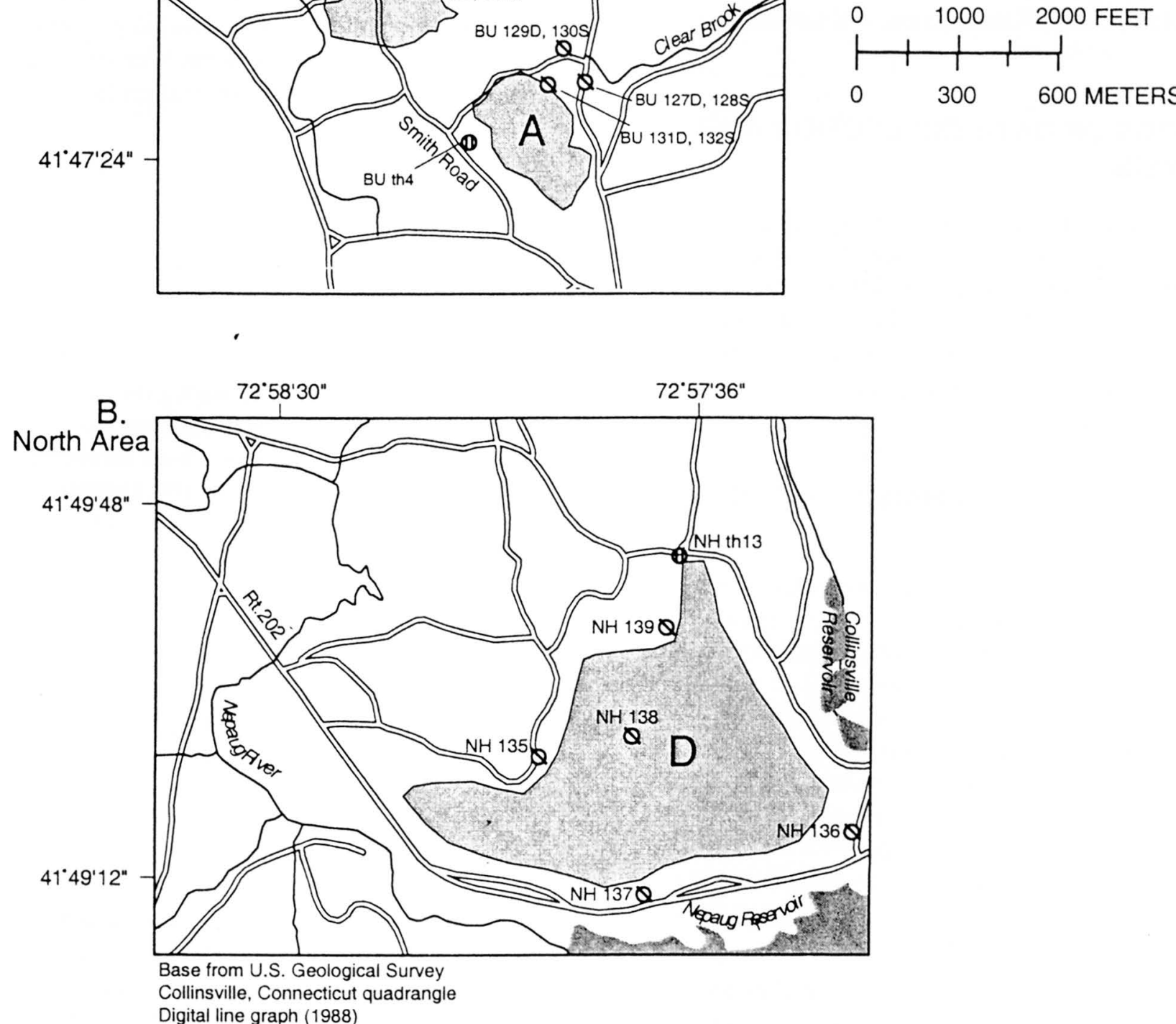

Figure 2. Location of roads, wells, test holes, and selected sand and gravel deposits in (A) the South Area and (B) the North Area, Nepaug Reservoir watershed, northwestern Connecticut (modified from Stone and others, 2001, fig. 3). 
The screened sand is used for winter ice control, and the remaining materials (tailings) are used primarily for service-road maintenance and rebuilding on MDC-owned properties. Three area towns-Farmington, Burlington, and Plainville-purchase and use approximately $20,000 \mathrm{yd}^{3}$ per year of the screened sand mined from the Nepaug Reservoir area. Burlington has purchased an average of $6,000 \mathrm{yd}^{3}$ per year for the last 12 years. Plainville has purchased $7,000 \mathrm{yd}^{3}$ per year for the last 5 years, and Farmington has purchased approximately $7,000 \mathrm{yd}^{3}$ per year. The MDC uses approximately $1,000 \mathrm{yd}^{3}$ per year of screened sand for winter ice control and another $1,000 \mathrm{yd}^{3}$ per year of tailings for maintenance and repair on access roads within their property boundaries (Leland Sanders, Metropolitan District Commission, oral commun., 2002).

\section{METHODS OF DATA COLLECTION AND ANALYSIS}

The methods used to study the hydrology and ground-water quality of the stratified glacial deposits in the North and South Areas in the Nepaug Reservoir watershed included (1) test-hole drilling and monitoring-well installation, (2) ground-water-level monitoring, (3) hydraulic (slug) testing, and (4) waterquality sampling.

\section{Test-Hole Drilling and Monitoring-Well Installation}

During the summer of 1998 , test holes were drilled and wells were installed to provide control points to confirm interpretations of seismic-refraction data (Stone and others, 2001, appendix 1), to provide locations for measuring ground-water levels and collecting ground-water samples for water-quality analysis, and to conduct hydraulic tests of the thick unconsolidated glacial deposits. Drilling sites were selected to provide spatial coverage of the study area, to represent different parts of the flow regime (hillside, hilltop, and valley), and to characterize different thicknesses of the sand and gravel deposits.

Sixteen monitoring wells and two test holes were drilled in the South Area (fig. 2A; table 1), and five monitoring wells and one test hole were drilled in the North area (fig. 2B; table 1). Test holes and monitoring wells were installed with a hollow-stem auger drill rig using methods described by Lapham and others (1997).
Split-spoon samples of the surficial materials were collected at 10 -ft intervals down to bedrock or refusal during the drilling process to determine lithology.

In the South Area, most monitoring wells were installed in pairs-a deep well with a 5 - $\mathrm{ft}$ section of 0.010 -in. slotted well screen (labeled 'D"), and a shallow well with a $10-\mathrm{ft}$ section of 0.010 -in. slotted well screen straddling the water table (labeled "S"). In the North Area, single monitoring wells were installed with a 5 -ft section of 0.010 -in. slotted well screen below the water table. Two exceptions to well-screen length are well BU-134D in the South Area, which has a 15-ft well screen section, and well NH-139 in the North Area, which has a 6-ft well screen section. Water levels in paired shallow and deep wells were used to determine if there is an upward or downward gradient. Well pairs were not installed in the North Area, because the saturated thickness is thin and vertical gradients would be very small.

\section{Ground-Water-Level Monitoring}

Ground-water levels were measured at monitoring wells in the study area to determine groundwater-level response times, vertical gradients, and the range of ground-water-level fluctuations in wells. Well BU-135 in the South Area was dry during the entire study period so no water-level measurements were collected at this location. Water levels were measured using two different methods: (1) manually, approximately every 2 weeks; or (2) continuously, with a submersible pressure transducer/data logger.

\section{Hydraulic Testing of Wells}

Slug tests were conducted in seven monitoring wells (BU-127D, BU-129D, BU-136D, BU-138D, $\mathrm{NH}-136, \mathrm{NH}-137$, and NH-138) using an air-pressurized method to induce an instantaneous change in the water column in the well. The tests were used to determine horizontal hydraulic conductivities of sand and gravel deposits. The slug tests were analyzed using (1) methods and equations described by Bouwer and Rice (1976) for unconfined aquifers with partially penetrating wells and short screens, and (2) methods described by Cooper and others (1967) for confined aquifers with fully penetrating wells using the type curve match-point method. Although few of the wells fully penetrate the aquifer, useful information still can be derived using this analysis method with partially 
Table 1. Selected construction and lithologic data for monitoring wells and test holes in the Nepaug Reservoir watershed, northwestern Connecticut

[Modified from Stone and others, 2001, appendix 2; USGS, U.S. Geological Survey; well pair-D, deep. S, shallow; BU, Burlington; NH, New Hartford; th, test hole; NA, not applicable]

\begin{tabular}{|c|c|c|c|c|}
\hline $\begin{array}{c}\text { USGS } \\
\text { local } \\
\text { well } \\
\text { number }\end{array}$ & $\begin{array}{l}\text { Total depth of } \\
\text { well/test hole } \\
\text { (feet below } \\
\text { land surface) }\end{array}$ & $\begin{array}{l}\text { Screened } \\
\text { interval } \\
\text { (feet below } \\
\text { land } \\
\text { surface) }\end{array}$ & $\begin{array}{l}\text { Description of material at } \\
\text { screened interval }\end{array}$ & $\begin{array}{c}\text { Depth to } \\
\text { bedrock } \\
\text { or refusal } \\
\text { (feet below land } \\
\text { surface) }\end{array}$ \\
\hline \multicolumn{5}{|c|}{ South Area } \\
\hline $\mathrm{BU}-127 \mathrm{D}$ & 49 & 44 to 49 & Sand, fine; silt; pebbles & 51 (refusal) \\
\hline BU-128S & 25 & 15 to 25 & Sand, coarse to medium & NA \\
\hline BU-129D & 40 & 35 to 40 & $\begin{array}{l}\text { Sand, coarse; silt; some } \\
\text { angular pebbles }\end{array}$ & 50 (refusal) \\
\hline BU-130S & 13 & 3 to 13 & Sand and gravel & NA \\
\hline BU-131D & 62 & 57 to 62 & $\begin{array}{l}\text { Sand, medium; silt; } \\
\text { some granules; till }\end{array}$ & 63 (refusal) \\
\hline BU-132S & 50 & 40 to 50 & $\begin{array}{l}\text { Sand, coarse to medium; silt; some } \\
\text { granules }\end{array}$ & $\mathrm{NA}$ \\
\hline BU-133S & 20 & 15 to 20 & Till & NA \\
\hline BU-134D & 26 & 11 to 26 & Sand and gravel; till & 26 (bedrock) \\
\hline BU-135 & 57 & 47 to 57 & Sand and gravel & $\mathrm{NA}$ \\
\hline BU-136D & 30 & 25 to 30 & Sand, coarse to fine; pebbles & 33 (refusal) \\
\hline BU-137S & 25 & 15 to 25 & $\begin{array}{l}\text { Sand, medium, layers of coarse and } \\
\text { fine; gravel }\end{array}$ & NA \\
\hline BU-138D & 60 & 57.5 to 62.5 & $\begin{array}{l}\text { Sand, coarse to medium, } \\
\text { layers of fine to very fine; pebbles }\end{array}$ & 101 (bedrock) \\
\hline BU-139S & 45 & 35 to 45 & $\begin{array}{l}\text { Sand, coarse to medium, } \\
\text { layers of fine to very fine }\end{array}$ & NA \\
\hline BU-140D & 110 & 115 to 120 & Till & NA \\
\hline BU-141S & 80 & 70 to 80 & Sand, coarse to medium & $\mathrm{NA}$ \\
\hline BU-142 & 52 & 47 to 52 & Till & 61 (refusal) \\
\hline BU-th-4 & 71 & $\mathrm{NA}$ & NA & 71 (bedrock) \\
\hline BU-th-5 & 80 & $\mathrm{NA}$ & NA & $\mathrm{NA}$ \\
\hline \multicolumn{5}{|c|}{ North Area } \\
\hline NH-135 & 125 & 120 to 125 & Sand, medium; some granules & NA \\
\hline NH-136 & 80 & 75 to 80 & Sand, fine to very fine & 80 (bedrock) \\
\hline NH-137 & 25 & 20 to 25 & $\begin{array}{l}\text { Sand, medium to very fine; } \\
\text { granular gravel }\end{array}$ & 47 (refusal) \\
\hline NH-138 & 100 & 95 to 100 & Sand, medium to fine & 120 (bedrock) \\
\hline NH-139 & 75 & 69 to 75 & Till & 77 (bedrock) \\
\hline NH-th-13 & 60 & $\mathrm{NA}$ & NA & NA \\
\hline
\end{tabular}


penetrating wells. The vertical conductivities of unconsolidated stratified aquifers often are very small in relation to the horizontal conductivities (Starn and others, 2000, p.13), so that the flow induced during a shortduration slug test is basically horizontal or two-dimensional. The methods described by Cooper and others (1967) yield a value for the transmissivity of the part of the aquifer being tested. The horizontal hydraulic conductivity value can then be determined by dividing the transmissivity by the saturated thickness of the aquifer at the well location. The hydraulic conductivity determined by slug tests, therefore, represents the part of aquifer in which the well is screened, but the conductivity can be inferred to represent the entire aquifer, if the aquifer is relatively homogeneous and isotropic. Both analytical methods use graphical solutions; therefore, slight variations in the results can occur depending on the accuracy of the graph construction and subjective judgments in matching field data to type curves and determining coefficients used in the solution equations.

To perform slug tests, a wellhead apparatus was constructed using a length of 2-in. polyvinyl chloride (PVC) well casing, a quick-release valve, assorted couplers, and a strain-relief connector. The column of air in the well was pressurized using a portable air tank with a built-in pressure valve. Water-level changes in the well were recorded using a submersible pressure transducer/data logger set at a 1-second logging interval and (or) water-level changes of $0.01 \mathrm{ft}$. A portable computer was used to monitor water-level changes during the test period. The pressure transducer was suspended inside the wellhead apparatus through a strain-relief connector that could be tightened around the cable to prevent air leakage past the cable. The apparatus was secured to the top of the well casing using a rubber coupling with clamps at each end to create an airtight seal between the wellhead apparatus and the well casing.

The pressure transducer was lowered into the well to a point at least $10 \mathrm{ft}$ below the water level. The data logger component of the instrument was connected to a portable computer allowing continuous real-time monitoring of water-level changes. After the water level in the well had returned to the level prior to insertion of the pressure transducer, the system was pressurized with approximately $5 \mathrm{lb} / \mathrm{in}^{2}$ of air from a portable air tank to induce a minimum 5 - $\mathrm{ft}$ change in water level. The water level was monitored until the pre-test water-level depth was achieved once again. A quick-release valve was then opened to release the air pressure in the well casing and begin the recovery portion of the slug test. The water level was allowed to recover to within a few hundredths of a foot of the original pre-test water level, at which time the test was terminated. Multiple slug tests were performed at five wells to determine the reproducibility of the results.

\section{Water-Quality Sampling}

Water samples were collected from 11 monitoring wells (BU-127D, BU-128S, BU-130S, BU132S, BU-133S, BU-137S, BU-140D, BU-141S, BU$142, \mathrm{NH}-137$, and $\mathrm{NH}-138$ ) to characterize the groundwater quality of the glacial deposits. Samples were collected in May 1999 and from August through September 1999 to determine ground-water quality, and whether there were any seasonal differences in water quality in the study area. Additional samples from three wells (BU-127D, BU-128S, and BU-132S) were collected in October 1999.

Water samples were collected from monitoring wells using a small positive-displacement submersible pump constructed of stainless steel and Teflon components. These observation wells were sampled using the USGS sampling methods described by Wilde and others (1999). Field parameters-temperature, dissolved oxygen, $\mathrm{pH}$, and specific conductance-were monitored during well purging, and samples were collected after all parameters had stabilized. Parameters were considered stable when three consecutive readings yielded the same value. The samples were sent to the USGS National Water-Quality Laboratory in Colorado for analysis of major inorganic compounds and nutrients. Using methods described by Radtke and Wilde (1998), an alkalinity titration was performed on a filtered sample in the field at the time of sampling. In addition to the regular samples collected, one quality-assurance/quality-control (QA/QC) sample also was collected.

\section{HYDROLOGY OF GLACIAL DEPOSITS IN THE NEPAUG RESERVOIR WATERSHED}

Glacial deposits in the Nepaug Reservoir watershed can be subdivided into till and stratified glacial deposits; the stratified deposits can be further subdivided into coarse-grained units and fine-grained units. Coarse-grained deposits store and transmit water to streams more readily than do till or fine-grained glacial 
deposits. The quantity of coarse-grained glacial stratified deposits in a watershed is a control on groundwater-level fluctuations and surface-water-flow characteristics (Stone and others, 2001). Because mining these deposits may affect the hydrology of the watershed, additional data were collected in phase 2 of this study to try to quantify the hydrologic importance of the glacial deposits.

Two concepts were developed regarding the hydrology of the study area: (1) that thick coarsegrained deposits of sand and gravel have the capacity to store rainfall and release that water slowly to streams, thus decreasing high streamflows and increasing low streamflows; and (2) that peaks in ground-water levels related to seasonal fluctuations occur later (in the year) with increasing thicknesses of coarse-grained unsaturated deposits. Data collected on ground-water levels, hydraulic properties, and the interaction between surface water and ground water are related to these two concepts in the following sections.

\section{Ground-Water Levels}

Changes in ground-water levels can be used to determine how quickly ground water responds to precipitation (ground-water-level response times), vertical hydraulic gradients, and the range of groundwater storage. Ground-water levels change when the amount of water recharging a basin or system is greater or smaller than the combined total of the amount of water discharging to surface-water bodies, the amount lost from the system by evapotranspiration processes, and the amount of ground-water withdrawals.

Typically, water levels in Connecticut begin to rise in October and reach their highest levels in May. Ground-water levels generally decline from May to September because water input (recharge) is less than output (discharge, evapotranspiration, and pumpage).

Ground-water storage, which is directly related to changes in saturated thickness, increases and decreases as ground-water levels rise and fall. Assuming the specific yield to be equal to 0.25 (Stone and others, 2001), one acre of land can store about $10,890 \mathrm{ft}^{3}$ of water for each foot of water-level rise. The ranges of water levels and thicknesses of glacial deposits are shown in table 2. Water levels for three groups of wells (Clear Brook, Phelps Brook, and the Nepaug River) are shown in figures 3,4 , and 6 .

\section{South Area}

Hydrographs of water-level data collected from September 1998 through December 2000 illustrate two periods of high and low ground-water levels that coincide with typical periods of recharge and discharge/ evapotranspiration of ground water in Connecticut (figs. 3, 4). Hydrographs for all wells in the South Area generally show steady increases from January 1999 to May 1999 and from September 1999 to June 2000, and generally show steady decreases from June to September 1999 and June to December 2000. The total difference in water-level fluctuations from September 1998 to December 2000 ranged from $1.64 \mathrm{ft}$ in well BU-133S to $7.51 \mathrm{ft}$ in well BU-132S (table 2).

Water levels in wells near Clear Brook (BU127D, BU-128S, BU-129D, BU-130S, BU-131D and $\mathrm{BU}-132 \mathrm{~S}$ ) are shown in figure 3. Water levels declined through the end of 1998 and did not begin to rise until January 1999 because of drought conditions in the previous fall. The intense rainfall from Tropical Storm Floyd on September 16 and 17, 1999 (about 8.5 in. over 2 days near the Nepaug Reservoir) led to an abrupt rise in water levels, probably caused by infiltration of surface water and recharge of ground water at the toe of slopes, followed by a short decline as these effects dissipated. Water levels rose until June 2000. The continued rise was, in part, the normal seasonal rise of water levels and possibly the slow infiltration of rainfall from Tropical Storm Floyd through the thick unsaturated deposits. The seasonal rise in ground-water levels in wells near Clear Brook, such as BU-131D or BU-142 (fig. 3) in water years 1999 to 2000 (after Floyd) was about the same rise as in water years 1998 to 1999 (before Floyd). These data from Clear Brook support the first concept that the deposits store large amounts of water and then slowly release the water to streams. Rainfall from Tropical Storm Floyd entered the sand and gravel deposits (the abrupt rise) and was slowly released.

Two well pairs near Clear Brook have upward gradients (BU-127D/128S and BU-129D/130S), indicating that ground water is discharging upward toward the surface and into Clear Brook (fig. 3; table 2). Water levels typically fluctuate less near discharge areas, and this is true of these Clear Brook wells. Water levels in wells BU-127D or BU-129D fluctuate only about $4 \mathrm{ft}$, whereas water levels in the recharge area on the hillside above Clear Brook fluctuate about $8 \mathrm{ft}$ (for example, well BU-131D had a water-level range of $7.50 \mathrm{ft}$ ). 
Table 2. Range of water levels in wells and unsaturated and saturated thicknesses of glacial deposits, Nepaug Reservoir watershed, northwestern Connecticut

[USGS, U.S. Geological Survey; BU, Burlington; NH New Hartford; well pair-D, deep, S, shallow; --, range of thickness only calculated for watertable (shallow) wells; numbers may not match because of rounding differences; vertical component of gradient shown for well pairs]

\begin{tabular}{|c|c|c|c|c|c|}
\hline $\begin{array}{l}\text { USGS } \\
\text { local well } \\
\text { number }\end{array}$ & $\begin{array}{c}\text { Range of water } \\
\text { levels } \\
\text { (altitude above } \\
\text { NAVD 88) }\end{array}$ & $\begin{array}{c}\text { Total } \\
\text { difference in } \\
\text { range of } \\
\text { water levels } \\
\text { (feet) }\end{array}$ & $\begin{array}{l}\text { Range of } \\
\text { thickness of } \\
\text { unsaturated } \\
\text { deposits } \\
\text { (feet below } \\
\text { land surface) }\end{array}$ & $\begin{array}{l}\text { Range of } \\
\text { thickness of } \\
\text { saturated } \\
\text { deposits } \\
\text { (feet above } \\
\text { bedrock/ } \\
\text { refusal) }\end{array}$ & $\begin{array}{c}\text { Vertical } \\
\text { component } \\
\text { of gradient }\end{array}$ \\
\hline \multicolumn{6}{|c|}{ South Area-Clear Book wells } \\
\hline BU-127D & $662.35-666.20$ & 3.85 & - & -- & \multirow{2}{*}{ Up } \\
\hline BU-128S & $661.70-664.63$ & 2.93 & $18.4-21.4$ & $29.6-32.6$ & \\
\hline BU-129D & $663.50-667.21$ & 3.71 & -- & -- & \multirow[b]{2}{*}{ Up } \\
\hline BU-130S & $662.47-666.10$ & 3.63 & $3.7-7.4$ & $42.6-46.3$ & \\
\hline BU-131D & $667.55 \cdot 675.05$ & 7.50 & -- & -- & \multirow[b]{2}{*}{ None } \\
\hline BU-132S & $667.69-675.20$ & 7.51 & $41.9-49.4$ & $13.6-21.1$ & \\
\hline \multicolumn{6}{|c|}{ South Area-Phelps Brook wells } \\
\hline BU-133S & $706.06-707.70$ & 1.64 & $6.9-8.6$ & $17.4-19.1$ & \multirow[b]{2}{*}{ None } \\
\hline BU-134D & $705.84-707.55$ & 1.71 & -- & -- & \\
\hline BU-136D & $706.29-708.87$ & 2.58 & - & -- & \multirow[b]{2}{*}{ None } \\
\hline BU-137S & $706.28-708.91$ & 2.63 & $17.5-20.1$ & $12.9-15.5$ & \\
\hline BU-138D & $706.27-708.80$ & 2.53 & .- & -. & \multirow{2}{*}{ None } \\
\hline BU-139S & $706.29 \cdot 708.80$ & 2.51 & $32.1-34.6$ & $66.4-68.9$ & \\
\hline BU-140D & $709.65-711.94$ & 2.29 & -- & -- & \multirow[b]{2}{*}{ Down } \\
\hline BU-141S & $710.32-712.58$ & 2.26 & $73.3-78.9$ & $41.1-46.7$ & \\
\hline BU-142 & $676.67-678.67$ & 2.00 & $22.0-24.8$ & $36.2-39.0$ & \\
\hline \multicolumn{6}{|c|}{ North Area wells } \\
\hline NH-135 & $560.91-564.03$ & 3.52 & $106.0-109.1$ & $15.9-19.0$ & \\
\hline NH-136 & $473.18-483.05$ & 9.87 & $35.0-44.9$ & $35.2-45.0$ & \\
\hline NH-137 & $526.89-527.94$ & 1.05 & $4.5-5.5$ & $41.5-42.5$ & \\
\hline NH-138 & $566.48-569.41$ & 2.93 & $67.9-70.8$ & $49.2-52.1$ & \\
\hline NH-139 & $558.58-562.51$ & 3.93 & $58.7-62.6$ & $14.4-18.4$ & \\
\hline
\end{tabular}




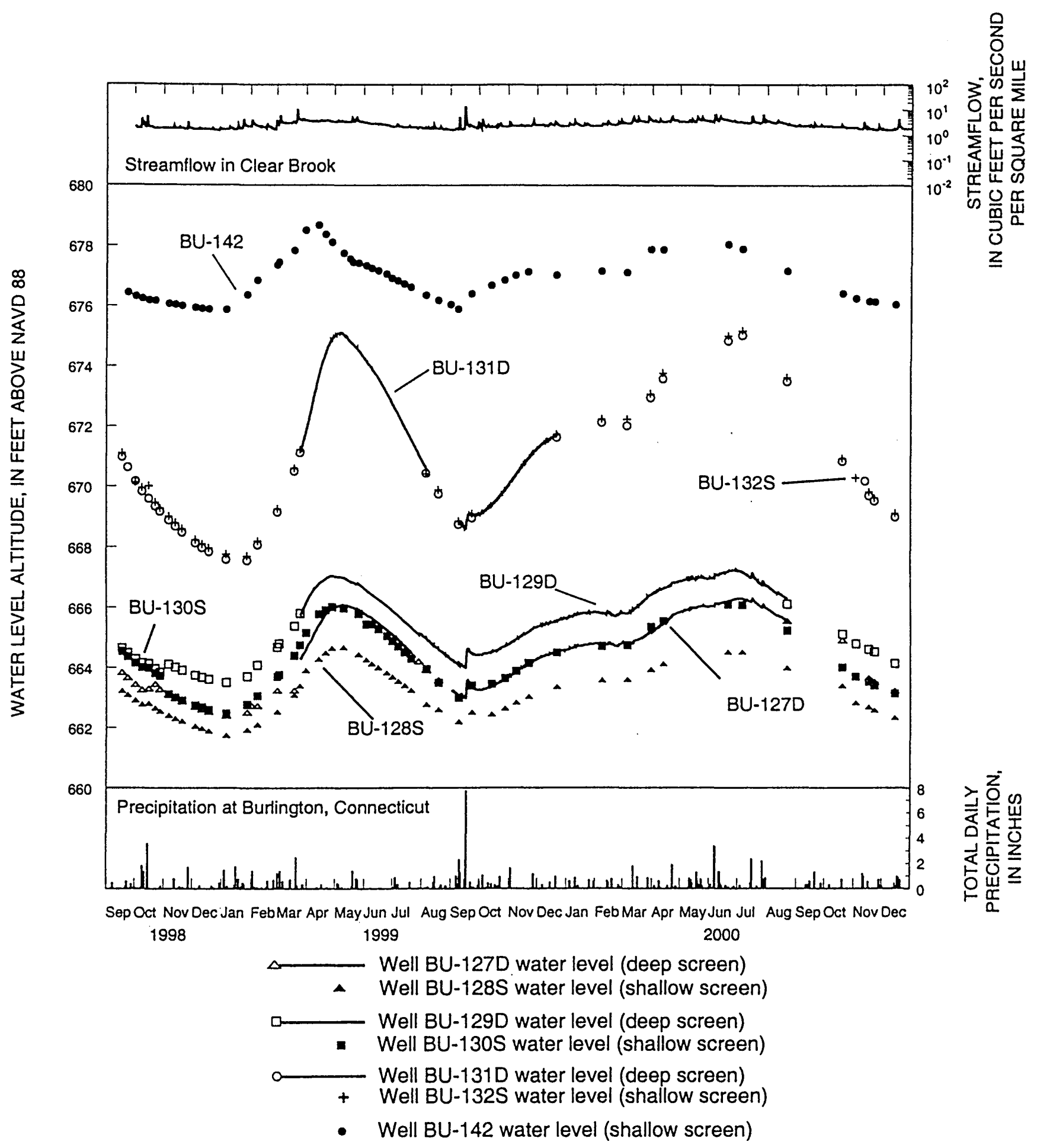

Figure 3. Water-level fluctuations in Clear Brook wells (BU-127D, BU-128S, BU-129D, BU-130S, BU-131D, BU-132S, and BU-142; South Area) compared to streamflow in Clear Brook and daily precipitation at Burlington, northwestern Connecticut, September 1998 to December 2000. 
Water levels in wells near Phelps Brook (BU133S, BU-134D, BU-136D, BU-137S, BU-138D, BU139S, BU-140D, and BU-141S) are shown in figure 4. Water levels in wells near Phelps Brook responded to Tropical Storm Floyd similarly to the Clear Brook group of wells, although the water-level measurements were not continuous in these wells, so the abrupt rise after Floyd was not recorded. These data also support the first concept of storage and slow release to streams because ground-water levels begin to rise after the storm.

Water levels in wells BU-140D and BU-141S have a downward gradient, indicating that ground water is recharging through the deposit (fig. 4; table 2). The range of fluctuation of water levels in this group of wells (about $3 \mathrm{ft}$ ) is less than in the Clear Brook group of wells (about 4 to $8 \mathrm{ft}$ ).

The timing of the peaks in ground-water levels can be seen in figure 5 . No relation seems to be present between thickness of the unsaturated deposits and the time of the ground-water peaks; this would seem to not support the second concept-that the time of the peak is later with increasing thickness of sand and gravel-in the South Area. Peaks in ground-water levels in the South Area seem to be more related to surface-water levels than to the thickness of the unsaturated deposits.

\section{North Area}

Water levels in wells near the Nepaug River (NH-135 through NH-139) are shown in figure 6. Water levels increased from March to June 1999 and February to August 2000. The level in well NH-137 (near the valley bottom) seems to be related to streamflow in the Nepaug River. The total difference in waterlevel fluctuations from September 1998 to December 2000 in the North Area ranged from a low of $1.05 \mathrm{ft}$ in well NH-137 to a high of $9.87 \mathrm{ft}$ in well NH-136 (table 2).

Water-level fluctuations in the North Area wells are markedly different than in the South Area wells. Wells NH-135, NH-138, and NH-139 in the North Area show seasonal water-level fluctuations, but peaks in ground-water levels are later in the season than in South Area wells. Water levels in these North Area wells did not rise abruptly after Tropical Storm Floyd (fig. 7). Although there was no abrupt rise after Floyd, the ground-water peaks still support the first concept, that the deposits store water and slowly release it. The delay in the rainfall response is caused by a difference in the bedrock geometry between the North and South Areas, which is described later.

The thickness of the unsaturated zone is greater in the North Area wells (59 to $109 \mathrm{ft}$, table 2) than in most other wells. Again, the timing of the highest water levels varies; in the North Area wells, the timing is in order of increasing thickness of the unsaturated deposits (fig. 7). This observation supports the second concept, that the peak in ground-water levels occurs later with increasing thickness of sand and gravel deposits. After the intense precipitation (about 8.5 in.) delivered by Tropical Storm Floyd on September 16 and 17,1999 , water levels continued to decline in three North Area wells with large thicknesses of unsaturated materials ( $\mathrm{NH}=135$, average unsaturated thickness of $107 \mathrm{ft}$; NH-138, average unsaturated thickness of $69 \mathrm{ft}$; and $\mathrm{NH}-139$ average unsaturated thickness of $61 \mathrm{ft}$ ). Levels declined until February 2000, illustrating the dampening effect of thick zones of unsaturated materials.

Although the thickness of the unsaturated deposits is a factor in water-level changes in the North Area, other differences between the North and South areas also cause differences in water-level response, specifically the geometry of the bedrock surface. The South Area can be thought of as a bowl-shaped depression in the bedrock surface that is filled with water and sand. The water table is flat, and changes in water levels, whether from surface water or ground water, spread quickly throughout the bowl. The North Area can be thought of as a freely draining sand deposit on the side of a bedrock hill, and changes in surface-water levels (other than at NH-137) do not spread upward through the deposit to appreciably affect ground-water levels. This difference explains why the South Area data do not support the second concept. The thickness of the unsaturated deposits is less important because ground-water-level increases are affected more by surface-water levels and by toe-of slope recharge. There are no short-term water level increases in the North Area (no abrupt rise after Tropical Storm Floyd) because there is less connection to surface water and because the toe-of-slope areas are farther from the wells. 


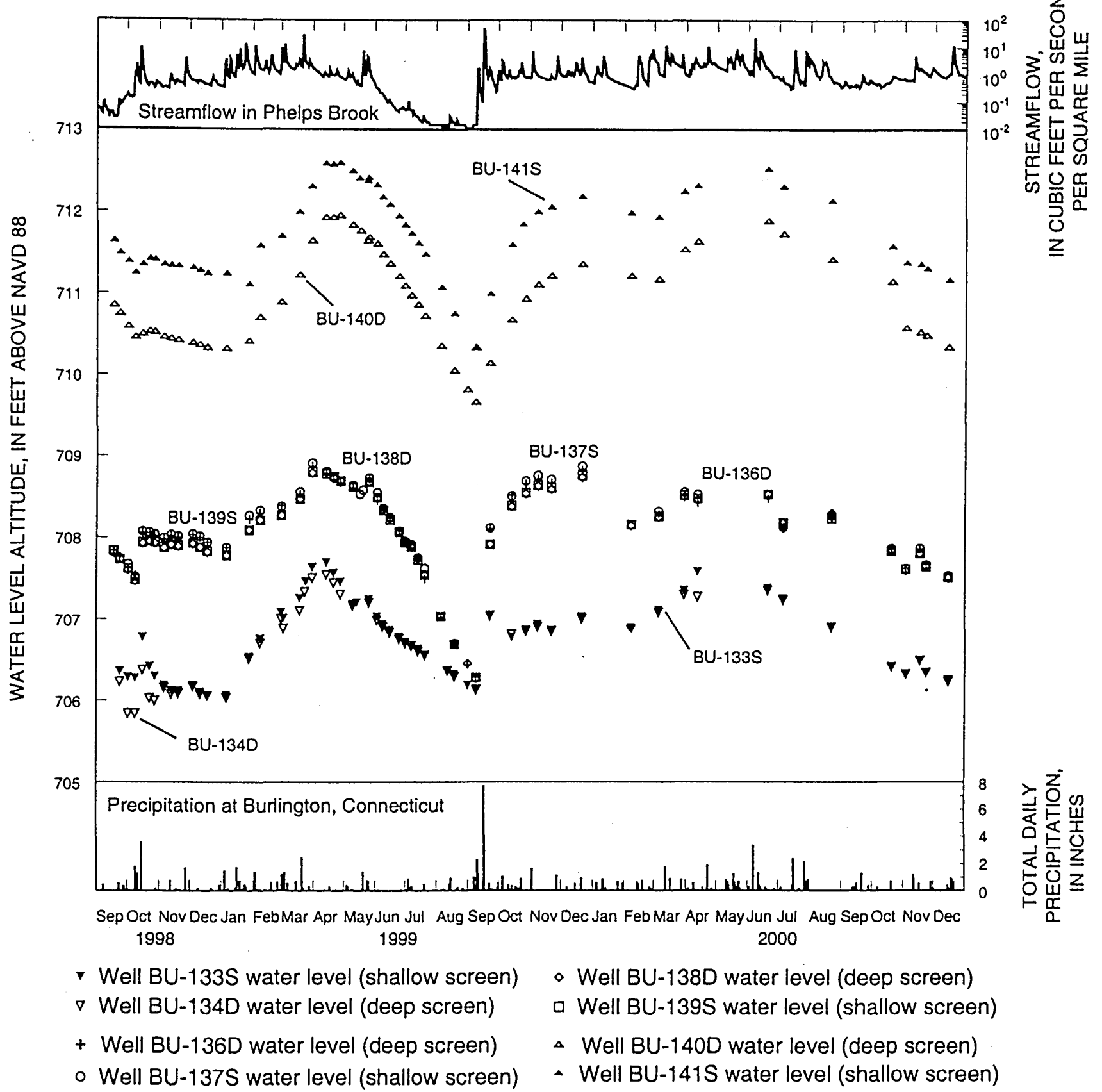

Figure 4. Water-level fluctuations in Phelps Brook wells (BU-133S, BU-134D, BU-136D, BU-137S, BU-138D, BU-139S, $B U-140 D$ and BU-141S; South Area), compared to streamflow in Phelps Brook and daily precipitation at Burlington, northwestern Connecticut, September 1998 to December 2000. 


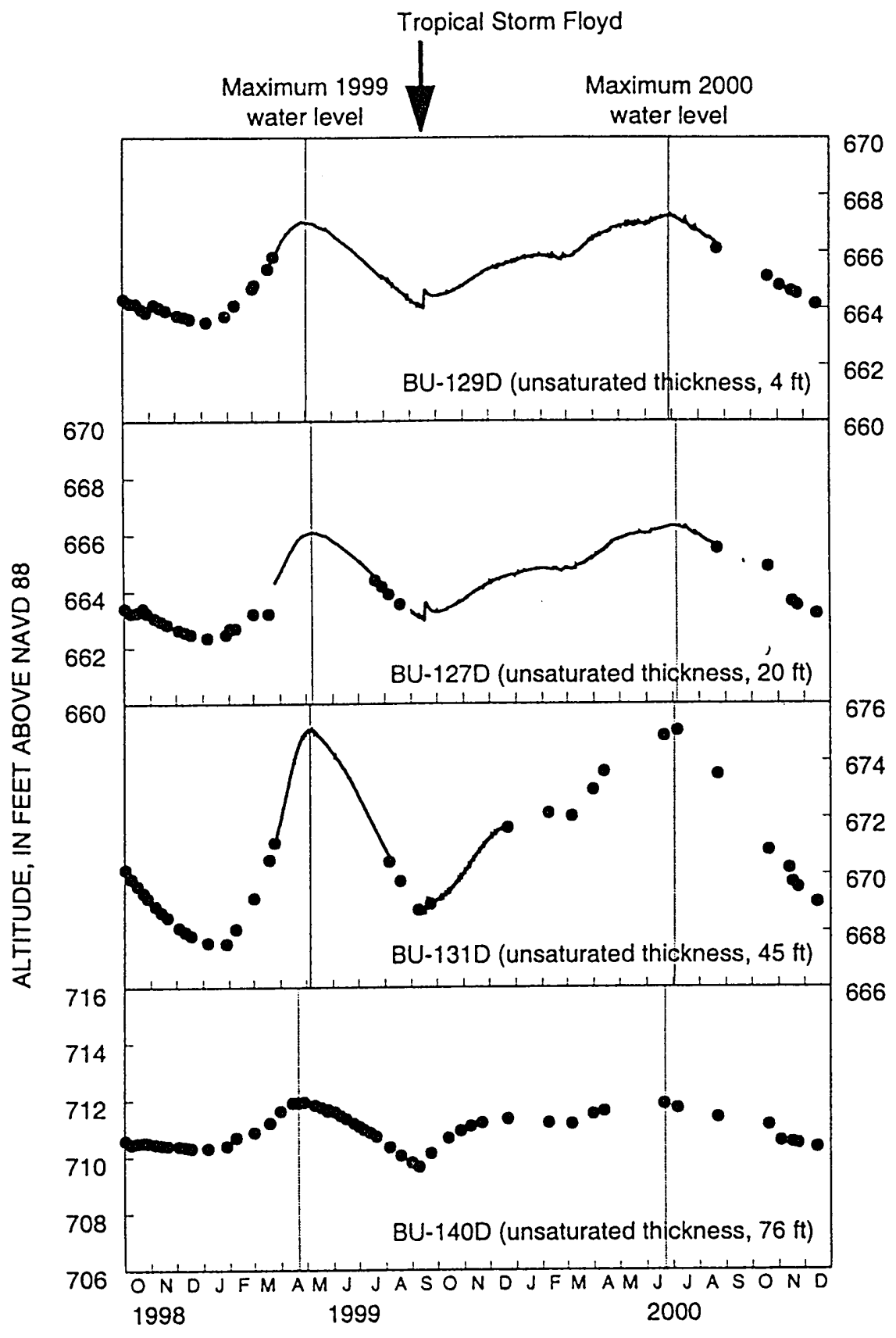

Figure 5. Differences in timing of highest water-levels and thickness of unsaturated deposits in wells BU-127D, BU-129D, BU-131D, and BU-140D (South Area), Nepaug Reservoir watershed, northwestern Connecticut, September 1998 to December 2000. 


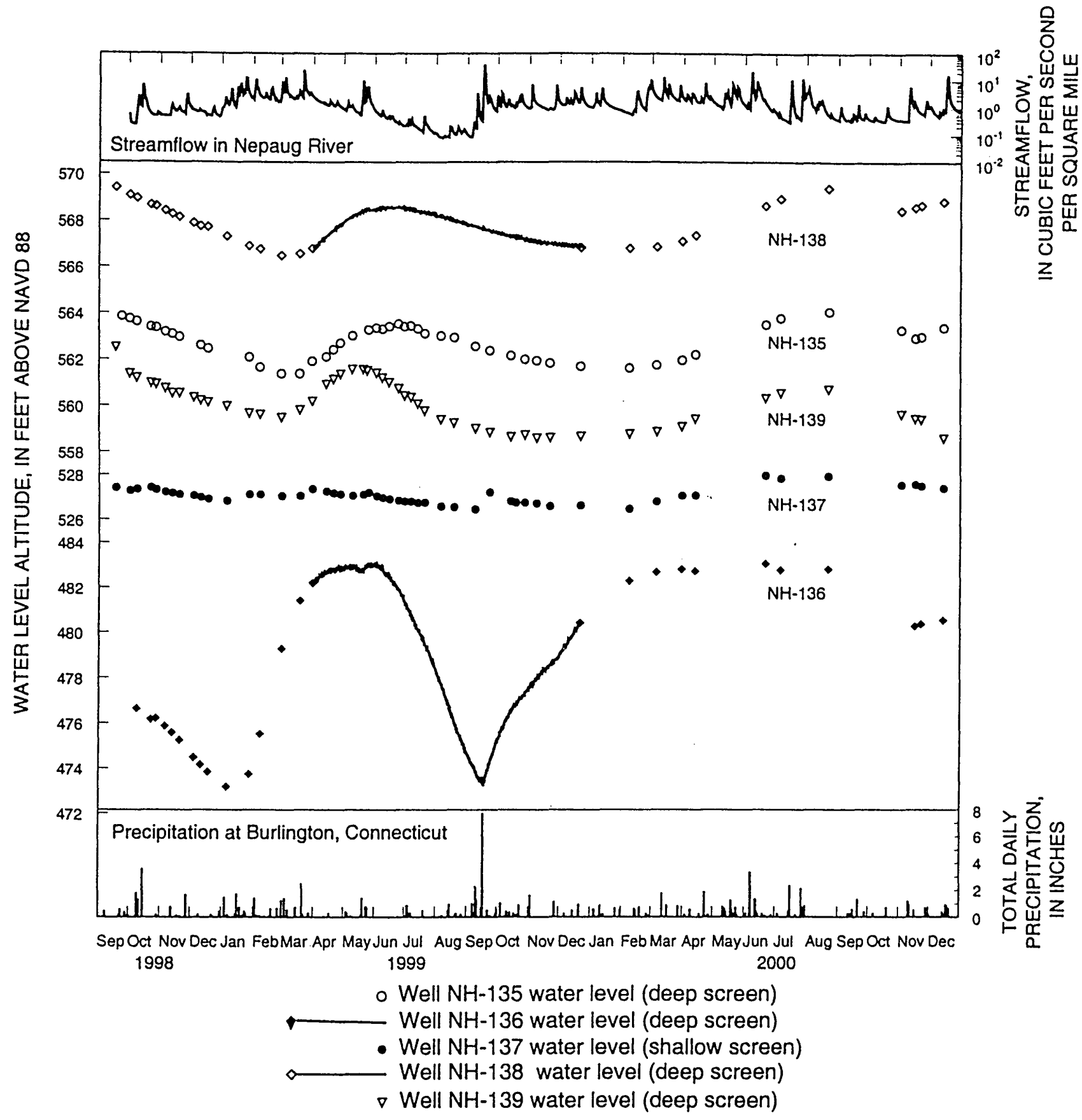

Figure 6. Water-level fluctuations in the Nepaug River wells ( $\mathrm{NH}-135$ to $\mathrm{NH}-139$; North Area), compared to streamflow in Nepaug River and daily precipitation at Burlington, northwestern Connecticut, September 1998 to December 2000. 


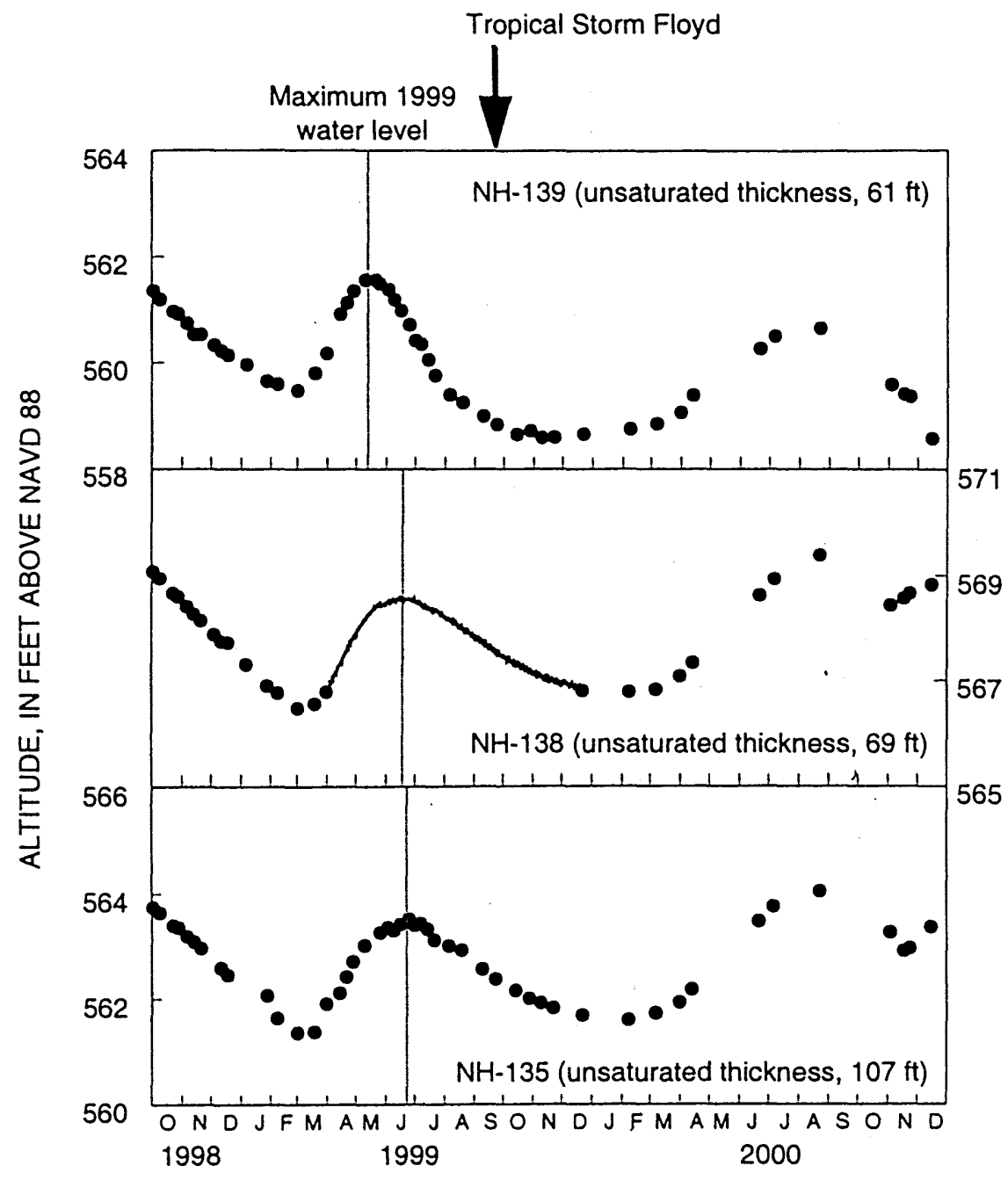

Figure 7. Differences in timing of highest water-levels and thickness of unsaturated deposits in wells $\mathrm{NH}-135, \mathrm{NH}-138$, and $\mathrm{NH}-139$ (North Area) Nepaug Reservoir watershed, northwestern Connecticut, September 1998 to December 2000.

\section{Hydraulic Properties}

Hydraulic conductivity values indicate how much water can flow through an aquifer for a unit hydraulic gradient. Slug tests conducted in wells BU127D, BU-129D, BU-136D, and BU-138D in the South Area yielded horizontal hydraulic conductivity values of the stratified glacial deposits that range from 0.93 to $19.9 \mathrm{ft} / \mathrm{d}$. Slug tests conducted in wells $\mathrm{NH}-136, \mathrm{NH}-$ 137 , and NH-138 in the North Area yielded horizontal hydraulic conductivity values of the stratified glacial deposits that range from 4.3 to $23.5 \mathrm{ft} / \mathrm{d}$ (table 3). These hydraulic conductivity values are similar to published ranges for unconsolidated sediments, which include-well-sorted gravel ( 28.4 to $2,835 \mathrm{ft} / \mathrm{d}$ ); wellsorted sands ( 2.8 to $283.5 \mathrm{ft} / \mathrm{d}$ ); silty sand and fine sand (0.028 to $2.8 \mathrm{ft} / \mathrm{d})$; silt, sandy silts, clayey sands, and till $(0.0028$ to $0.28 \mathrm{ft} / \mathrm{d})$; and clay $(0.000003$ to $0.0028 \mathrm{ft} / \mathrm{d})$ (Fetter, 2001). 
Table 3. Calculated hydraulic conductivity values from slug tests in monitoring wells, Nepaug Reservoir watershed, northwestern Connecticut

[USGS, U.S. Geological Survey; BU, Burlington; NH, New Hartford; well pair-D, deep, S, shallow]

\begin{tabular}{|c|c|c|c|c|c|}
\hline $\begin{array}{c}\text { USGS } \\
\text { local well } \\
\text { number }\end{array}$ & $\begin{array}{l}\text { Date slug } \\
\text { test(s) } \\
\text { conducted }\end{array}$ & $\begin{array}{c}\text { Horizontal } \\
\text { hydraulic } \\
\text { conductivity } \\
\text { (calculated using } \\
\text { method described by } \\
\text { Bouwer and Rice, } \\
\text { 1976) } \\
\text { (feet per day) }\end{array}$ & $\begin{array}{c}\text { Horizontal } \\
\text { hydraulic } \\
\text { conductivity } \\
\text { (calculated using } \\
\text { method described by } \\
\text { Cooper and others, } \\
\text { 1967) } \\
\text { (feet per day) }\end{array}$ & $\begin{array}{c}\text { Screened } \\
\text { interval } \\
\text { (feet below } \\
\text { land } \\
\text { surface) }\end{array}$ & $\begin{array}{c}\text { Description of } \\
\text { material in } \\
\text { screened } \\
\text { interval }\end{array}$ \\
\hline $\begin{array}{l}\text { BU-127D } \\
\text { test } 1 \\
\text { test } 2\end{array}$ & $\begin{array}{l}7 / 29 / 99 \\
7 / 29 / 99\end{array}$ & $\begin{array}{l}6.2 \\
9.2\end{array}$ & $\begin{array}{r}6.8 \\
12.9\end{array}$ & $44-49$ & $\begin{array}{l}\text { Sand, fine; silt; } \\
\text { pebbles }\end{array}$ \\
\hline $\begin{array}{l}\text { BU-129D } \\
\text { test } 1 \\
\text { test } 2\end{array}$ & $\begin{array}{l}7 / 29 / 99 \\
7 / 29 / 99\end{array}$ & $\begin{array}{l}1.3 \\
1.4\end{array}$ & $\begin{array}{l}1.4 \\
1.8\end{array}$ & $35-40$ & $\begin{array}{l}\text { Sand, coarse; silt; } \\
\text { some angular } \\
\text { pebbles }\end{array}$ \\
\hline BU-136D & $9 / 1 / 99$ & 7.2 & 19.9 & $\begin{array}{c}25-30 \\
\text {, }\end{array}$ & $\begin{array}{l}\text { Sand, fine to } \\
\text { coarse; pebbles }\end{array}$ \\
\hline $\begin{array}{c}\text { BU-138D } \\
\text { test } 1 \\
\text { test } 2 \\
\text { test } 3\end{array}$ & $\begin{array}{l}8 / 24 / 99 \\
8 / 24 / 99 \\
9 / 1 / 99\end{array}$ & $\begin{array}{l}1.4 \\
0.93 \\
1.4\end{array}$ & $\begin{array}{l}1.8 \\
1.8 \\
2.9\end{array}$ & $55-60$ & $\begin{array}{l}\text { Sand, coarse to } \\
\text { medium, layers } \\
\text { of fine to yery } \\
\text { fine; pebbles }\end{array}$ \\
\hline $\begin{array}{r}\text { NH-136 } \\
\text { test } 1 \\
\text { test } 2\end{array}$ & $\begin{array}{l}10 / 29 / 99 \\
10 / 29 / 99\end{array}$ & $\begin{array}{l}11.4 \\
16.7\end{array}$ & $\begin{array}{l}20.9 \\
23.5\end{array}$ & $75-80$ & $\begin{array}{l}\text { Sand, fine to very } \\
\text { fine }\end{array}$ \\
\hline $\begin{array}{c}\text { NH-137 } \\
\text { test } 1 \\
\text { test } 2 \\
\text { test } 3\end{array}$ & $\begin{array}{l}10 / 19 / 99 \\
10 / 19 / 99 \\
10 / 29 / 99\end{array}$ & $\begin{array}{l}6.2 \\
6.6 \\
8.3\end{array}$ & $\begin{array}{r}11.8 \\
16.2 \\
6.8\end{array}$ & $20-25$ & $\begin{array}{l}\text { Sand, very fine to } \\
\text { medium; some } \\
\text { granular gravel }\end{array}$ \\
\hline NH-138 & 10/29/99 & 4.5 & 4.3 & $95-100$ & $\begin{array}{l}\text { Sand, fine to } \\
\text { medium }\end{array}$ \\
\hline
\end{tabular}

\section{Interaction Between Ground Water and Surface Water}

Ground water contributes to streamflow, especially during summer low-flow periods and droughts. Summer is a critical time for water supply because demand is highest and many plants and animals depend on aquatic habitat in summer. Rainfall that reaches the water table (recharge) eventually discharges to streams as baseflow. If changes in ground-water storage are small, the mean annual ground-water recharge should be approximately equal to the mean annual baseflow to streams. Mean annual ground-water recharge is calculated by multiplying the area of coarse-grained glacial deposits (about 540 acres) by the typical ground-water recharge for coarse-grained glacial deposits (about
$22 \mathrm{in} / \mathrm{yr}$; Starn and others, 2000). In the South Area, the mean annual ground-water recharge is about $1.4 \mathrm{ft}^{3} / \mathrm{s}$. This ground water flows to either Phelps or Clear Brook; however, in some summers, it may flow only to Clear Brook and cause Phelps Brook to go dry. The mean annual streamflow for Clear Brook is $1.5 \mathrm{ft}^{3} / \mathrm{s}$, so the contribution of ground water to this stream is very important. The area of coarse-grained glacial deposits in the North area also is about 540 acres, so this area should produce about the same amount $\left(1.4 \mathrm{ft}^{3} / \mathrm{s}\right)$ of baseflow to the Nepaug River. The mean annual streamflow in the Nepaug River is $38.1 \mathrm{ft}^{3} / \mathrm{s}$, so the ground-water contribution to streamflow is a smaller percentage in the Nepaug River than in Clear Brook; however, the contribution to the Nepaug River is still 
important for maintaining summer streamflow, when the mean streamflow is only $2.4 \mathrm{ft}^{3} / \mathrm{s}$.

Streamflow data from the South and North Areas support the concept that sand and gravel deposits store rainfall and release it slowly. During this study, streamflow in Clear Brook varied by less than an order of magnitude, despite the small size of the drainage area $\left(0.59 \mathrm{mi}^{2}\right)$ and the large amount of rainfall during Tropical Storm Floyd. The remarkably consistent streamflow in Clear Brook (fig. 3) has helped lessen the effects of historical floods and droughts (Stone and others, 2001). The thickness of the sand and gravel deposits, and the fact that much of the thickness is unsaturated, allows most of the ground-water recharge to be stored and released slowly to Clear Brook. By contrast, streamflow in Phelps Brook is highly variable (fig. 4), and the brook is dry in some summers.

The Nepaug River (North Area) is intermediate between Clear and Phelps Brooks in terms of the relation between surface water and ground water. The Nepaug River responds to rainfall (fig. 6 ) but did not go dry during the study period because it has a much larger drainage area than Clear or Phelps Brooks. Groundwater levels near the Nepaug River show the same pattern of seasonal rise and decline as the surface-water hydrographs; however, there is a long lag between peaks in ground-water levels and streamflow. Although there are thick deposits of sand and gravel in the North Area, the Nepaug River Basin has a lower percentage of sand and gravel than the Clear Brook basin.

The concept that sand and gravel deposits store rainfall and release it slowly also is supported by streamflow data that were used to compare the groundwater and surface-water drainage areas for streams in the Nepaug Reservoir watershed. Long-term streamflow data are available for Burlington Brook (19322001), Clear Brook (1955-1973), and the Nepaug River (1955, 1958-1984). Median winter streamflow (January through March), divided by drainage area and converted to cubic feet per second per square mile, is similar among these three streams (fig. 8). Median summer streamflow (July through September), however, indicates that discharge from Clear Brook is much higher than expected (fig. 8). Additional shortterm data collected during this study indicate that Phelps Brook discharge is lower than expected and is dry in some summers. One explanation for the observed summer streamflows is that Clear Brook receives ground-water inflow from the Phelps Brook surface-water drainage area. In other words, the ground-water drainage area of Clear Brook is larger than its surface-water drainage area.
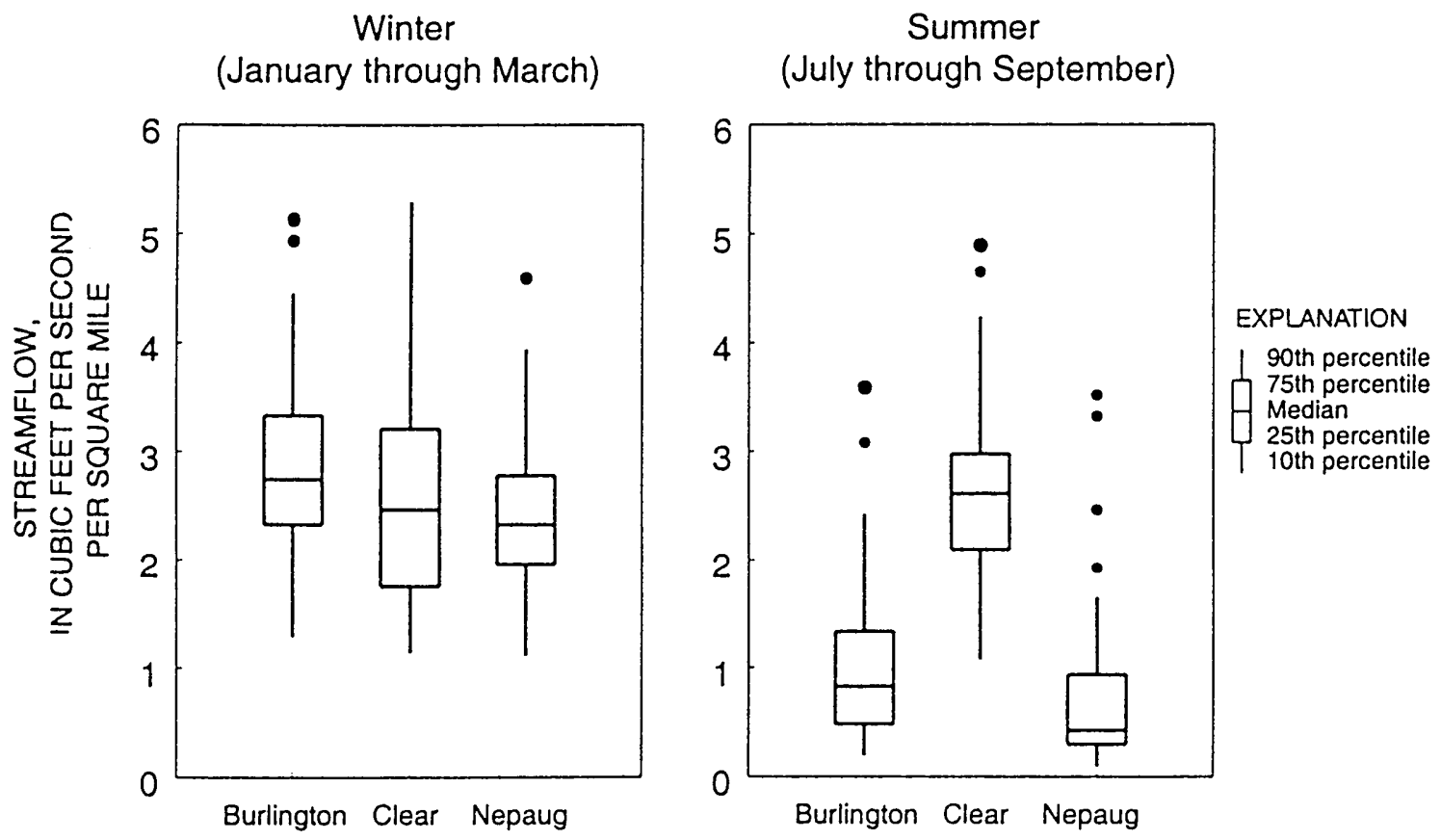

Figure 8. Difference in median winter streamflow (January through March), and median summer streamflow (July through September), Burlington Brook, Clear Brook, and Nepaug River, Nepaug Reservoir watershed, northwestern Connecticut. 


\section{Hydrologic Importance of the Glacial Deposits}

The hydrologic responses of Nepaug Reservoir watershed to drought conditions and a tropical storm during the study period illustrate the hydrologic effects of the stratified glacial deposits. Areas of thin stratified glacial deposits are analogous to areas that have been mined, so the hydrologic effect of mining can be seen in the differences between hydrologic responses in areas having thick or thin stratified glacial deposits.

Two hydrologic observations of the Nepaug Reservoir watershed can be used to assess the effects of mining: (1) there is a longer lag time between precipitation and rises in ground-water levels in the North Area than in the South Area, and (2) streamflow is higher than expected in Clear Brook and lower than expected in Phelps Brook, especially in summer. The large rainfall from Tropical Storm Floyd was largely absorbed by the stratified glacial deposits in the North Area. The effect of this was twofold: more water was stored to sustain flow in the Nepaug River during summer low-flow periods, and conversely, less water was contributed to high flows. The erosive potential of the Nepaug River is reduced because of the reduction in high flows. The time delay (lag time) between Tropical Storm Floyd and water-level rises seems to have increased with increasing thickness of unsaturated deposits. By analogy, mining, which reduces the thickness of the unsaturated zone, would probably result in a quicker response to large amounts of rainfall, such as occurred during Tropical Storm Floyd.

Water-level rises in the South Area are not related to thickness of the unsaturated deposits, but instead are related to the geology and physiography of the area. The initial water-level rises after Tropical Storm Floyd were caused by the infiltration of rainfall at the toe of slopes, which then spread laterally beneath the deposits. Again, by analogy, if this area were mined and the slopes reduced, it would probably result in faster ground-water recharge and probably a higher water table.

The steady seasonal streamflow in Clear Brook can be attributed to the large ground-water watershed that feeds it and the large quantities of ground water that can be stored in the stratified glacial deposits. The large ground-water watershed, relative to the size of the surface-water watershed, is a result of the thick stratified glacial deposits that allow water to pass easily from the Phelps Brook watershed into Clear Brook.
The time lag between infiltration and discharge into Clear Brook allows the effects of climate variations to be mitigated.

\section{GROUND-WATER QUALITY IN GLACIAL DEPOSITS IN THE NEPAUG RESERVOIR WATERSHED}

Ground-water samples for water-quality analysis were collected in May 1999 and in August through September 1999 to compare seasonal differences. The analyses included measurements of field parameters (table 4), concentrations of nutrients and dissolved organic carbon (table 4), and major inorganic compounds and dissolved solids (table 5). Wells BU127D, BU-128S, and BU-132S were resampled for organic carbon on Oçtober 18, 1999 because of large concentrations of organic carbon measured from the August through September sampling (table 4).

Samples collected in May were intended to represent ground-water quality during a recharge period, and samples collected in August through September were intended to represent ground-water quality during a low streamflow period. Prior to each sampling, this relation held true-rainfall was 12.9 in. from April to May and was 5.1 in. from June to August. Unfortunately, the samples did not represent the intended conditions because both sets of samples were collected after large rainfalls-May 4 through May 9 (1.04 in.) and August 11 through August 22 (2.1 in.).

Measured values of $\mathrm{pH}$ during both sampling rounds ranged from 5.6 to 8.0 standard units (table 4). The $\mathrm{pH}$ values measured in wells BU-140D and BU$141 S$, where a downward head gradient was observed (recharge zone of the study area), ranged from 5.7 to 6.1 standard units. The $\mathrm{pH}$ values in wells BU-127D and BU-128S, where an upward head gradient was observed (discharge zone of the study area), ranged from 6.0 to 7.0 standard units. Average $\mathrm{pH}$ values of precipitation collected by the National Atmospheric Deposition Program (NADP, 2002) at site "CT 15 Abington" in Windham, Connecticut (4.6) are lower than $\mathrm{pH}$ values measured during ground-water sampling in the study area, indicating that precipitation becomes less acidic as it travels through the aquifer from recharge areas to discharge areas. If the distance from recharge to discharge areas becomes less (through mining and removal of the stratified glacial deposits), there may be less $\mathrm{pH}$ buffering. 
Table 4. Field measurements and concentrations of nutrients and organic carbon in ground-water samples, Nepaug Reservoir watershed, northwestern Connecticut, May 1999 and August through October 1999

[All units in milligrams per liter unless otherwise noted; USGS, U.S. Geological Survey; BU, Burlington; NH, New Hartford; well pair--D, deep, S, shallow; ${ }^{\circ} \mathrm{C}$, degrees Celsius; SC, specific conductance; $\mu \mathrm{S} / \mathrm{cm}$, microsiemens per centimeter; DO, dissolved oxygen; $\mathrm{CaCO}$, calcium carbonate; $\mathrm{HCO}_{3}$, bicarbonate ion; $\mathrm{N}$, nitrogen; $\mathrm{P}$, phosphorus; DOC, dissolved organic carbon; <, less than;

E, estimated; NM, not measured]

\begin{tabular}{|c|c|c|c|c|c|c|c|c|c|c|c|c|c|c|}
\hline $\begin{array}{c}\text { USGS } \\
\text { local well } \\
\text { number } \\
\text { (fig. 2) }\end{array}$ & Date & $\begin{array}{c}\text { Water } \\
\text { tempera- } \\
\text { ture } \\
\left({ }^{\circ} \mathrm{C}\right)\end{array}$ & $\begin{array}{l}\text { pH, field } \\
\text { (stan- } \\
\text { dard } \\
\text { units) }\end{array}$ & $\begin{array}{c}\text { SC } \\
(\mu \mathrm{S} / \mathrm{cm})\end{array}$ & DO & $\begin{array}{l}\text { Alkalinity, } \\
\text { field } \\
\text { (as } \\
\mathrm{CaCO}_{3} \text { ) }\end{array}$ & $\begin{array}{l}\text { Bicarbon- } \\
\text { ate, field } \\
\text { (as } \mathrm{HCO}_{3} \text { ) }\end{array}$ & $\begin{array}{c}\text { Nitrogen, } \\
\text { ammonia } \\
\text { dissolved } \\
\text { (as N) }\end{array}$ & $\begin{array}{l}\text { Nitrogen, } \\
\text { ammonia+ } \\
\text { organic } \\
\text { dissolved } \\
\text { (as } N \text { ) }\end{array}$ & $\begin{array}{c}\text { Nitrogen, } \\
\mathrm{NO}_{2}+\mathrm{NO}_{3} \\
\text { dissolved } \\
\text { (as } \mathrm{N} \text { ) }\end{array}$ & $\begin{array}{l}\text { Nitrogen, } \\
\text { nitrite } \\
\text { dissolved } \\
\text { (as N) }\end{array}$ & $\begin{array}{l}\text { Phospho- } \\
\text { rus, } \\
\text { dissolved } \\
\text { (as P) }\end{array}$ & $\begin{array}{l}\text { Ortho- } \\
\text { phos- } \\
\text { phate, } \\
\text { dissolved } \\
\text { (as P) }\end{array}$ & $\begin{array}{l}\text { DOC } \\
\text { (as C) }\end{array}$ \\
\hline \multicolumn{15}{|c|}{ SPRING SAMPLING (MAY 1999) } \\
\hline \multicolumn{15}{|c|}{ North Area } \\
\hline $\mathrm{NH}-137$ & $5 / 21 / 99$ & 8.5 & 6.5 & 37 & 11.3 & 11 & 13 & $<0.02$ & $<0.10$ & $<0.05$ & $<0.010$ & $<0.004$ & 0.01 & .4 \\
\hline NH-138 & $5 / 26 / 99$ & 10.3 & 6.9 & 42 & NM & 13 & 16 & .03 & E.09 & $<.05$ & $<.010$ & .005 & .01 & 1.9 \\
\hline \multicolumn{15}{|c|}{ South Area } \\
\hline BU-127D & $5 / 13 / 99$ & 8.0 & 6.0 & 46 & 11.9 & 9 & 11 & $<.02$ & $<.10$ & .11 & $<.010$ & $<.004$ & $<.01$ & .4 \\
\hline BU-128S & $5 / 12 / 99$ & 7.5 & 7.0 & 51 & 12.5 & 7 & 8 & $<.02$ & $<.10$ & .39 & $<.010$ & .006 & $<.01$ & .4 \\
\hline BU-130S & $5 / 13 / 99$ & 8.2 & 6.7 & 46 & 10.4 & 4 & 4 & $<.02$ & $<.10$ & $<.05$ & $<.010$ & $<.004$ & $<.01$ & .5 \\
\hline BU-132S & $5 / 14 / 99$ & 9.0 & 6.0 & 47 & 11.8 & 9 & 11 & $<.02$ & $<.10$ & .12 & $<.010$ & $<.004$ & .01 & .7 \\
\hline BU-133S & $5 / 14 / 99$ & 7.5 & 8.0 & 39 & 9.8 & 12 & 15 & $<.02$ & $<.10$ & .06 & $<.010$ & .010 & .03 & .4 \\
\hline BU-137S & $5 / 20 / 99$ & 8.9 & 5.6 & 22 & 11.8 & 2 & 3 & $<.02$ & $<.10$ & $<.05$ & $<.010$ & $<.004$ & .01 & .3 \\
\hline BU-140D & $5 / 25 / 99$ & 10.6 & 5.7 & 84 & NM & 9 & 11 & .03 & E. 07 & .14 & $<.010$ & $<.004$ & $<.01$ & 2.2 \\
\hline BU-141S & $5 / 25 / 99$ & 10.5 & 6.0 & 32 & 10.8 & 6 & 7 & .03 & E.05 & $<.05$ & $<.010$ & .007 & .01 & 1.4 \\
\hline BU-142 & $5 / 20 / 99$ & 9.6 & 7.0 & 103 & 1.9 & 43 & 52 & $<.02$ & E. 05 & $<.05$ & $<.010$ & $<.004$ & .01 & .4 \\
\hline $\begin{array}{l}\text { Equip- } \\
\text { ment } \\
\text { blank }\end{array}$ & $5 / 11 / 99$ & $\mathrm{NM}$ & 7.4 & 1.6 & $\mathrm{NM}$ & NM & NM & $<.02$ & $\leqslant .10$ & $<.05$ & $<.010$ & $<.004$ & $<.01$ & .2 \\
\hline
\end{tabular}


Table 4. Field measurements and concentrations of nutrients and organic carbon in ground-water samples, Nepaug Reservoir watershed, northwestern Connecticut, May 1999 and August through October 1999-Continued

[All units in milligrams per liter unless otherwise noted; USGS, U.S. Geological Survey; BU, Burlington; NH, New Hartford; well pair--D, deep, S, shallow; ${ }^{\circ} \mathrm{C}$, degrees Celsius; SC, specific conductance; $\mu \mathrm{S} / \mathrm{cm}$, microsiemens per centimeter; DO, dissolved oxygen; $\mathrm{CaCO}$, calcium carbonate; $\mathrm{HCO}_{3}$, bicarbonate ion; $\mathrm{N}$, nitrogen; $\mathrm{P}$, phosphorus; $\mathrm{DOC}$, dissolved organic carbon; <, less than;

E. estimated; NM, not measured]

\begin{tabular}{|c|c|c|c|c|c|c|c|c|c|c|c|c|c|c|}
\hline $\begin{array}{c}\text { USGS } \\
\text { local well } \\
\text { number } \\
\text { (fig. 2) }\end{array}$ & Date & $\begin{array}{c}\text { Water } \\
\text { tempera- } \\
\text { ture } \\
\left({ }^{\circ} \mathrm{C}\right)\end{array}$ & $\begin{array}{l}\text { pH, field } \\
\text { (stan- } \\
\text { dard } \\
\text { units) }\end{array}$ & $\begin{array}{c}\mathrm{SC} \\
(\mu \mathrm{S} / \mathrm{cm})\end{array}$ & Do. & $\begin{array}{l}\text { Alkalinity, } \\
\text { field } \\
\text { (as } \\
\left.\mathrm{CaCO}_{3}\right)\end{array}$ & $\begin{array}{l}\text { Bicarbon- } \\
\text { ate, field } \\
\text { (as } \mathrm{HCO}_{3} \text { ) }\end{array}$ & $\begin{array}{l}\text { Nitrogen, } \\
\text { ammonia } \\
\text { dissolved } \\
\text { (as } N \text { ) }\end{array}$ & $\begin{array}{l}\text { Nitrogen, } \\
\text { ammonia+ } \\
\text { organic } \\
\text { dissolved } \\
\text { (as } N \text { ) }\end{array}$ & $\begin{array}{c}\text { Nitrogen, } \\
\mathrm{NO}_{2}+\mathrm{NO}_{3} \\
\text { dissolved } \\
\text { (as } \mathrm{N} \text { ) }\end{array}$ & $\begin{array}{c}\text { Nitrogen, } \\
\text { nitrite } \\
\text { dissolved } \\
\text { (as } N \text { ) }\end{array}$ & $\begin{array}{l}\text { Phospho- } \\
\text { rus, } \\
\text { dissolved } \\
\text { (as P) }\end{array}$ & $\begin{array}{l}\text { Ortho- } \\
\text { phos- } \\
\text { phate, } \\
\text { dissolved } \\
\text { (as P) }\end{array}$ & $\begin{array}{c}\text { DOC } \\
\text { (as C) }\end{array}$ \\
\hline \multicolumn{15}{|c|}{ SUMMER SAMPLING (AUGUST THROUGH OCTOBER 1999) } \\
\hline \multicolumn{15}{|c|}{ North Area } \\
\hline NH-137 & $9 / 2 / 99$ & 10.6 & 6.6 & 43 & 10.9 & 10 & 12 & $<.02$ & $<.10$ & $<.05$ & $<.010$ & .005 & $<.01$ & .7 \\
\hline NH-138 & $9 / 2 / 99$ & 10.6 & 6.7 & 47 & 8.9 & 12 & 15 & $<.02$ & $<.10$ & $<.05$ & $<.010$ & $<.004$ & $<.01$ & 1.4 \\
\hline \multicolumn{15}{|c|}{ South Area } \\
\hline BU-127D & $8 / 25 / 99$ & 10.2 & 6.3 & 58 & 10.5 & 6 & 8 & $<.02$ & $<.10$ & .20 & $<.010$ & $<.004$ & $<.01$ & 1.2 \\
\hline BU-127D & $10 / 18 / 99$. & 8.3 & NM & 57 & 7.6 & NM & NM & NM & NM & NM & NM & NM & NM & .9 \\
\hline BU-128S & $8 / 25 / 99$ & 12.9 & 6.5 & 59 & 9.3 & 7 & 9 & .02 & $<.10$ & .29 & $<.010$ & .004 & .01 & 5.0 \\
\hline BU-128S & $10 / 18 / 99$ & 10.7 & NM & 69 & 11 & NM & NM & NM & NM & NM & NM . & NM & NM & 2.2 \\
\hline BU-130S & $8 / 25 / 99$ & 15.5 & 6.0 & 44 & 3.5 & 3 & 4 & $<.02$ & $<.10$ & $<.05$ & $<.010$ & $<.004$ & $<.01$ & 2.2 \\
\hline BU-132S & $8 / 25 / 99$ & 14.2 & 6.1 & 58 & 10.2 & 6 & 7 & $<.02$ & $<.10$ & .29 & $<.010$ & $<.004$ & $<.01$ & 4.5 \\
\hline BU-132S & $10 / 18 / 99$ & 10.9 & $\mathrm{NM}$ & 57 & NM & NM & NM & NM & $\mathrm{NM}$ & NM & NM & NM & NM & E.2 \\
\hline BU-133S & $8 / 26 / 99$ & 12.4 & 6.9 & 48 & 9.0 & 11 & 14 & $<: 02$ & $<.10$ & .09 & $<.010$ & .009 & $<.01$ & .4 \\
\hline BU-137S & $8 / 26 / 99$ & 12.4 & 5.7 & 26 & 11.5 & 2 & 3 & $<.02$ & $<.10$ & $<.05$ & $<.010$ & $<.004$ & $<.01$ & .4 \\
\hline BU-140D & $8 / 24 / 99$ & 12.9 & 6.1 & 93 & 3.2 & 7 & 8 & $<.02$ & E.05 & .12 & $<.010$ & $<.004$ & $<.01$ & 3.4 \\
\hline BU-141S & 8/24/99 & 13.0 & 6.0 & 53 & 8.2 & 9 & 11 & $<.02$ & E.06 & $<.05$ & $<.010$ & .005 & $<.01$ & 1.5 \\
\hline BU-142 & $8 / 26 / 99$ & 14.6 & 7.1 & 115 & 1.3 & 40 & 49 & $<.02$ & $<.10$ & $<.05$ & $<.010$ & .006 & $<.01$ & .6 \\
\hline
\end{tabular}




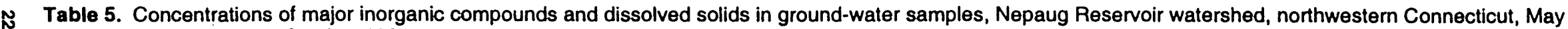
1999 and August through October 1999

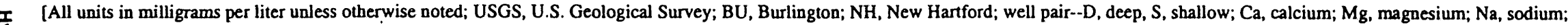
$\mathrm{K}$, potassium; $\mathrm{Cl}$, chloride; $\mathrm{SO}_{4}$, sulfate; $\mathrm{F}$, fluoride; $\mathrm{SiO}_{2}$, silica; $\mathrm{Fe}$, iron; $\mathrm{Mn}$, manganese; $\mu \mathrm{g} / \mathrm{L}$, micrograms per liter]

\begin{tabular}{|c|c|c|c|c|c|c|c|c|c|c|c|c|}
\hline $\begin{array}{l}\text { USGS } \\
\text { local well } \\
\text { number } \\
\text { (fig. 2) }\end{array}$ & Date & $\begin{array}{l}\text { Calcium, } \\
\text { dissolved } \\
\text { (as Ca) }\end{array}$ & $\begin{array}{l}\text { Magne- } \\
\text { sium, } \\
\text { dissolved } \\
\text { (as Mg) }\end{array}$ & $\begin{array}{l}\text { Sodium, } \\
\text { dissolved } \\
\text { (as Na) }\end{array}$ & $\begin{array}{l}\text { Potassium, } \\
\text { dissolved } \\
\text { (as K) }\end{array}$ & $\begin{array}{l}\text { Chloride, } \\
\text { dissolved } \\
\text { (as Cl) }\end{array}$ & $\begin{array}{l}\text { Sulfate, dis- } \\
\text { solved (as } \\
\left.\mathrm{SO}_{4}\right)\end{array}$ & $\begin{array}{c}\text { Fluoride, } \\
\text { dissolved } \\
\text { (as F) }\end{array}$ & $\begin{array}{c}\text { Silica, } \\
\text { dissolved } \\
\left.\text { (as } \mathrm{SiO}_{2}\right)\end{array}$ & $\begin{array}{c}\text { Iron, } \\
\text { dissolved } \\
(\mu \mathrm{g} / \mathrm{L} \text { as Fe })\end{array}$ & $\begin{array}{c}\text { Manganese, } \\
\text { dissolved } \\
(\mu \mathrm{g} / \mathrm{L} \text { as } \mathrm{Mn})\end{array}$ & $\begin{array}{l}\text { Solids, sum of } \\
\text { constituents, } \\
\text { dissolved }\end{array}$ \\
\hline \multicolumn{12}{|c|}{ SPRING SAMPLING (MAY 1999) } & . \\
\hline \multicolumn{13}{|c|}{ North Area } \\
\hline NH-137 & $5 / 21 / 99$ & 3.41 & 1.03 & 2.35 & .77 & 1.89 & 6.1 & $<.1$ & 12.2 & E 8 & 13.4 & 34 \\
\hline NH-138 & $5 / 26 / 99$ & 3.15 & 1.09 & 2.69 & 1.20 & 2.36 & 5.2 & $<.1$ & 12.3 & 21 & 216 & 36 \\
\hline \multicolumn{13}{|c|}{ South Area } \\
\hline BU-127D & $5 / 13 / 99$ & 2.36 & .911 & 4.69 & .83 & 5.41 & 5.4 & $<.1$ & 10.8 & E 5 & $<3.0$ & 36 \\
\hline BU-128S & $5 / 12 / 99$ & 2.85 & 1.21 & 4.44 & .85 & 4.88 & 8.0 & $<.1$ & 11.2 & $<10$ & $<3.0$ & 40 \\
\hline BU-130S & $5 / 13 / 99$ & 2.12 & .957 & 4.48 & .38 & 7.43 & $6.1^{\prime}$ & $<.1$ & 10.3 & $<10$ & 22.3 & 34 \\
\hline BU-132S & $5 / 14 / 99$ & 2.50 & 1.00 & 4.80 & $: 87$ & 6.14 & 5.8 & $<.1$ & 11.3 & E 8 & E 2.1 & 38 \\
\hline BU-133S & $5 / 14 / 99$ & 2.73 & 1.38 & 2.56 & .92 & 1.28 & 5.8 & $<.1$ & 13.2 & 18 & 9.2 & 36 \\
\hline BU-137S & $5 / 20 / 99$ & 1.06 & .417 & 1.24 & .59 & 1.32 & 6.1 & $<.1$ & 6.5 & $<10$ & 18.6 & 19 \\
\hline BU-140D & $5 / 25 / 99$ & 5.64 & 1.71 & 7.06 & .68 & 15.2 & 6.5 & $<.1$ & 12.9 & 132 & 348 & 56 \\
\hline BU-141S & $5 / 25 / 99$ & 2.38 & .891 & 2.13 & .30 & 2.15 & 5.1 & $<.1$ & 10.8 & E 8 & 14.0 & 27 \\
\hline BU-142 & $5 / 20 / 99$ & 7.92 & 3.94 & 6.27 & 3.33 & 4.65 & 6.7 & .2 & 18.5 & 33 & 1,340 & 79 \\
\hline $\begin{array}{l}\text { Equipment } \\
\text { blank }\end{array}$ & $5 / 11 / 99$ & .015 & .002 & $<.06$ & $<.1$ & $<.1$ & $<.1$ & $<.1$ & $<.05$ & $<10$ & 2.1 & \\
\hline
\end{tabular}


Table 5. Concentrations of major inorganic compounds and dissolved solids in ground-water samples, Nepaug Reservoir watershed, northwestern Connecticut, May 1999 and August through October 1999-Continued

[All units in milligrams per liter unless otherwise noted; USGS, U.S. Geological Survey; BU, Burlington; NH, New Hartford; well pair--D, deep, S, shallow; Ca, calcium; Mg, magnesium; Na, sodium;

$\mathrm{K}$, potassium; $\mathrm{Cl}$, chloride; $\mathrm{SO}_{4}$, sulfate; $\mathrm{F}$, fluoride; $\mathrm{SiO}_{2}$, silica; $\mathrm{Fe}$, iron; $\mathrm{Mn}$, manganese; $\mu \mathrm{g} / \mathrm{L}$, micrograms per liter]

\begin{tabular}{|c|c|c|c|c|c|c|c|c|c|c|c|c|}
\hline $\begin{array}{c}\text { USGS } \\
\text { local well } \\
\text { number } \\
\text { (fig. 2) }\end{array}$ & Date & $\begin{array}{l}\text { Calcium, } \\
\text { dissolved } \\
\text { (as Ca) }\end{array}$ & $\begin{array}{l}\text { Magne- } \\
\text { sium, } \\
\text { dissolved } \\
\text { (as } \mathbf{M g} \text { ) }\end{array}$ & $\begin{array}{l}\text { Sodium, } \\
\text { dissolved } \\
\text { (as Na) }\end{array}$ & $\begin{array}{l}\text { Potassium, } \\
\text { dissolved } \\
\text { (as K) }\end{array}$ & $\begin{array}{l}\text { Chloride, } \\
\text { dissolved } \\
\text { (as } \mathrm{Cl} \text { ) }\end{array}$ & $\begin{array}{c}\text { Sulfate, dis- } \\
\text { solved (as } \\
\left.\mathrm{SO}_{4}\right)\end{array}$ & $\begin{array}{c}\text { Fluoride, } \\
\text { dissolved } \\
\text { (as F) }\end{array}$ & $\begin{array}{c}\text { Silica, } \\
\text { dissolved } \\
\left(\text { as } \mathrm{SiO}_{2}\right)\end{array}$ & $\begin{array}{c}\text { Iron, } \\
\text { dissolved } \\
(\mu \mathrm{g} / \mathrm{L} \text { as } \mathrm{Fe})\end{array}$ & $\begin{array}{c}\text { Manganese, } \\
\text { dissolved } \\
(\mu g / L \text { as } M n)\end{array}$ & $\begin{array}{l}\text { Solids, sum of } \\
\text { constituents, } \\
\text { dissolved }\end{array}$ \\
\hline \multicolumn{13}{|c|}{ SUMMER SAMPLING (AUGUST THROUGH OCTOBER 1999) } \\
\hline \multicolumn{13}{|c|}{ North Area } \\
\hline NH-137 & $9 / 2 / 99$ & 3.09 & 1.09 & 2.37 & 2.33 & 1.55 & 4.2 & $<.1$ & 12.8 & $<10$ & 4.6 & 33 \\
\hline NH-138 & $9 / 2 / 99$ & 3.22 & 1.08 & 2.50 & 3.11 & 1.62 & 4.5 & $<.1$ & 12.6 & 20 & 94.5 & 36 \\
\hline \multicolumn{13}{|c|}{ South Area } \\
\hline BU-127D & $8 / 25 / 99$ & 2.76 & 1.04 & 5.12 & .93 & 6.01 & 4.6 & $<.1$ & 11.7 & E7 & $<3.0$ & 37 \\
\hline $\mathrm{BU}-128 \mathrm{~S}$ & $8 / 25 / 99$ & 2.95 & 1.19 & 4.92 & .95 & 5.63 & 4.8 & $<.1$ & 12.7 & E 5 & $<3.0$ & 39 \\
\hline BU-130S & $8 / 25 / 99$ & 1.71 & .827 & 3.99 & .29 & 5.02 & 5.1 & $<.1$ & 12.2 & E 8 & 26.7 & 31 \\
\hline BU-132S & $8 / 25 / 99$ & 2.76 & 1.05 & 5.42 & .93 & 5.71 & 4.8 & $<.1$ & 12.3 & 14 & $<3.0$ & 38 \\
\hline BU-133S & $8 / 26 / 99$ & 2.88 & 1.38 & 2.76 & 1.10 & 1.15 & 4.4 & $<.1$ & 14.6 & E 7 & 8.8 & 36 \\
\hline BU-137S & $8 / 26 / 99$ & 1.34 & .552 & 1.24 & .63 & 1.60 & 3.9 & $<.1$ & 7.3 & E9 & 18.4 & 18 \\
\hline$B U-140 D$ & $8 / 24 / 99$ & 5.61 & 1.64 & 6.95 & .84 & 13.9 & 6.1 & $<.1$ & 13.7 & 122 & 247 & 54 \\
\hline BU-141S & $8 / 24 / 99$ & 3.43 & 1.25 & 2.94 & .54 & 4.58 & 3.8 & $<.1$ & 11.8 & 19 & 44.4 & 34 \\
\hline BU-142 & $8 / 26 / 99$ & 8.04 & 3.88 & 5.87 & 3.44 & 4.14 & 4.2 & .1 & 19.8 & 21 & 1,170 & 75 \\
\hline
\end{tabular}


The concentrations of dissolved cations associated with neutral salts ( $\mathrm{Ca}, \mathrm{Mg}, \mathrm{Na}$, and $\mathrm{K}$ ) were compared (table 5). In the recharge zone (for example, wells BU-140D/BU-141S), concentrations were higher in water samples collected in the deep well than they were in the shallow well. In the discharge zone (for example, wells BU-127D/128S), concentrations were similar in the shallow and deep well pairs. In the shallow regional flow regime, infiltrating water comes in contact with gases in the unsaturated zone and shallow ground water resulting in localized, short-term reactions that dissolve minerals and degrade organic material. In the deep flow regime, long-term, slower chemical reactions, such as precipitation and dissolution of minerals and ion exchange, can add or remove solutes (Likens and Bormann, 1995).

Recorded ground-water temperatures were consistently greater during the late summer sampling than during the spring sampling (table 4). Temperatures measured in ground-water samples as they were pumped to the surface into a flow-through chamber ranged from 7.5 to $10.6^{\circ} \mathrm{C}$ in the spring and from 10.2 to $14.6^{\circ} \mathrm{C}$ in late summer. Temperatures also were higher in wells with thicker unsaturated zones-range of 10.3 to $13.0^{\circ} \mathrm{C}$ in BU-140D (76 ft), BU-141S (76 ft), and $\mathrm{NH}-138(69 \mathrm{ft})$ - as compared to wells with thinner unsaturated zones-range of 7.5 to $10.6^{\circ} \mathrm{C}$ in wells BU-130S (6 ft), BU-133S ( $8 \mathrm{ft}$ ) and NH-137 (5 ft). Measured specific conductance values showed the reverse effect, with a range from 37 to $96 \mu \mathrm{S} / \mathrm{cm}$ in the wells with thicker unsaturated zones and 42 to 51 $\mu S / \mathrm{cm}$ in the wells with thinner unsaturated zones.

Dissolved oxygen concentrations, which are in part a function of temperature, showed a reverse seasonal trend to temperature, with dissolved oxygen concentrations decreasing from spring to late summer (table 4). The only other parameters that showed a consistent seasonal change between the spring and late summer samples were sulfate and silica (table 5). Sulfate concentrations were consistently lower in the late summer samples, and silica concentrations were lower in the spring samples.

Ion concentrations in water samples collected during both sampling rounds are illustrated using Stifftype pattern diagrams in figures 9 and 10. The spring and late summer diagrams are quite similar. 


\section{RECHARGE AREA}

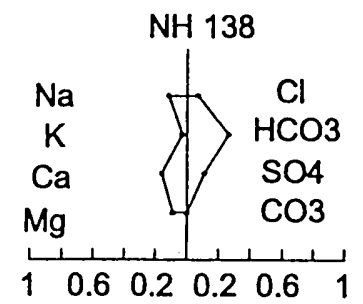

Milliequivalents per liter

\section{DISCHARGE AREA}

North Area

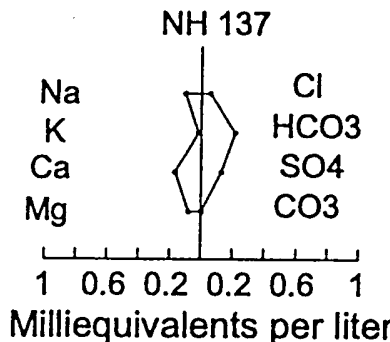

\section{South Area}

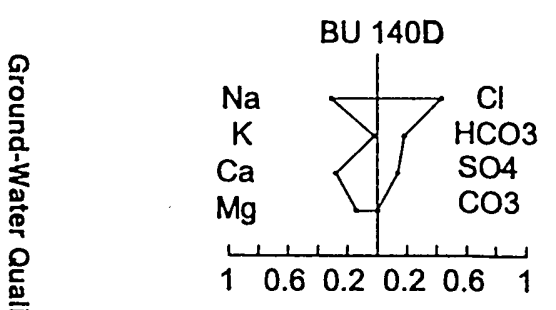

Milliequivalents per liter

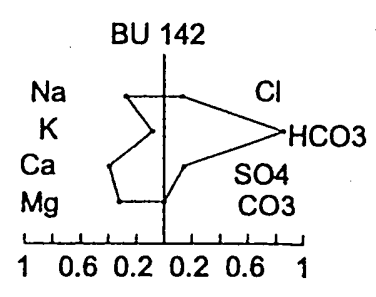

Milliequivalents per liter

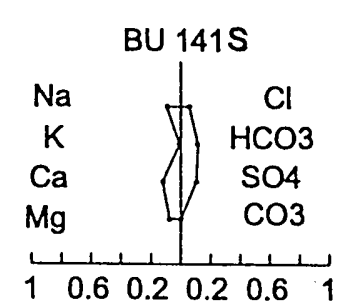

Milliequivalents per liter

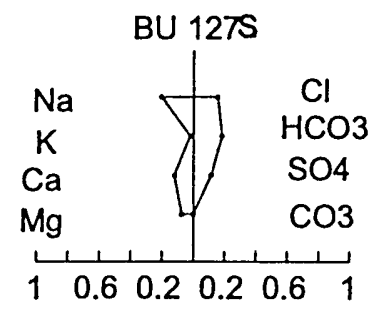

Milliequivalents per liter

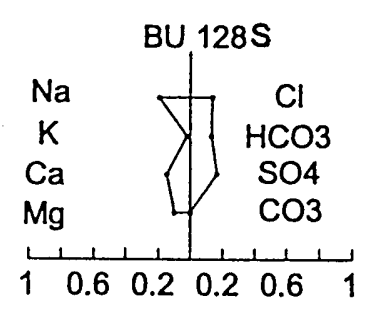

Milliequivalents per liter

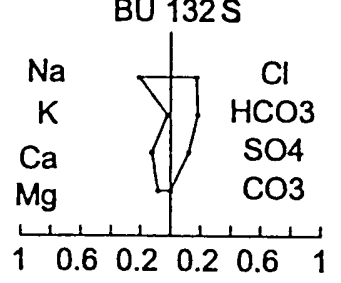

Milliequivalents per liter

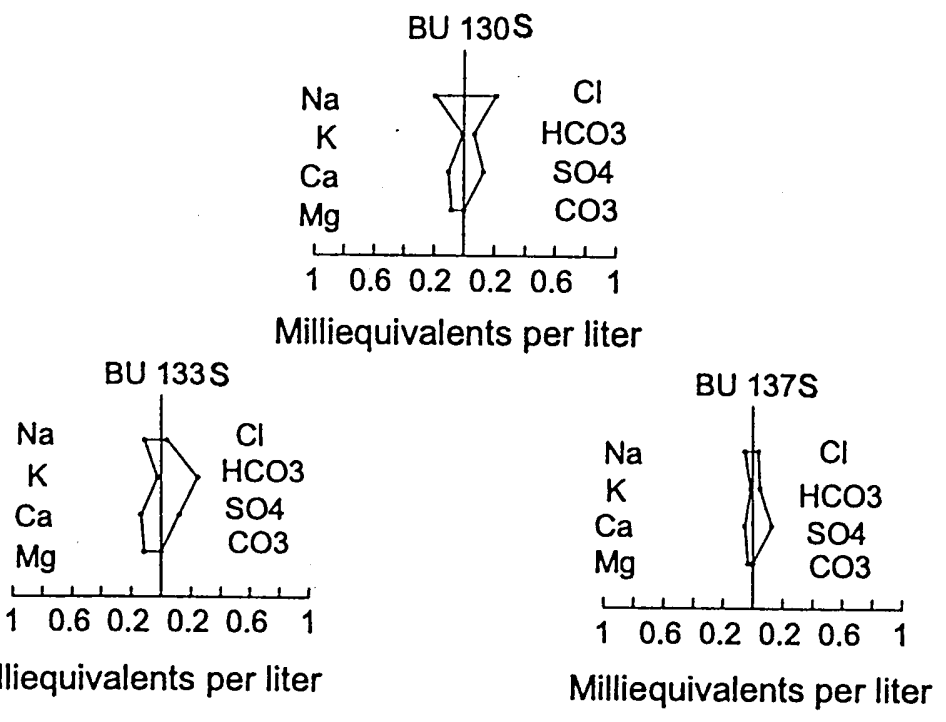

Milliequivalents per liter 


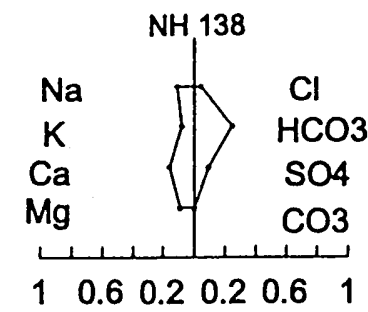

Milliequivalents per liter
North Area

\section{South Area}

\section{DISCHARGE AREA}

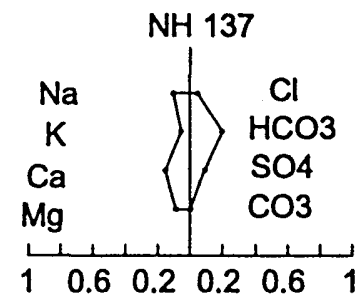

Milliequivalents per liter

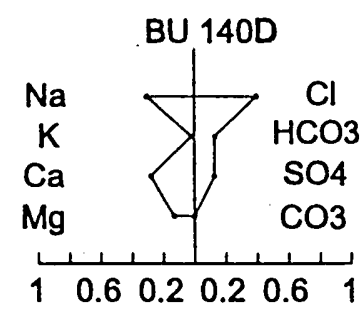

Milliequivalents per liter

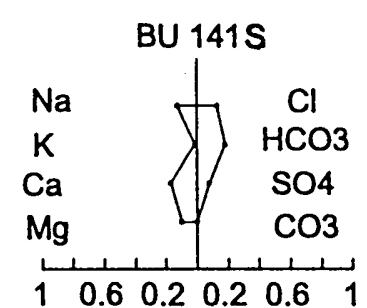

Milliequivalents per liter

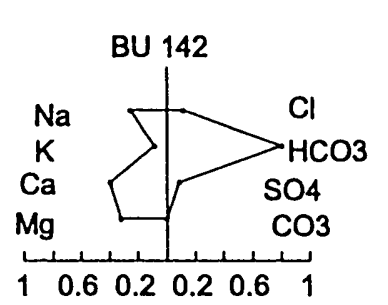

Milliequivalents per liter

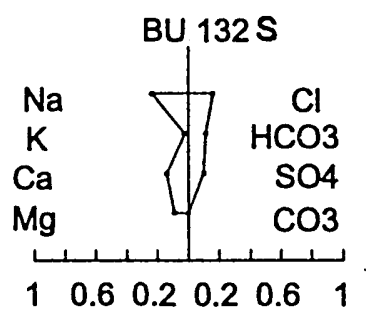

Milliequivalents per liter

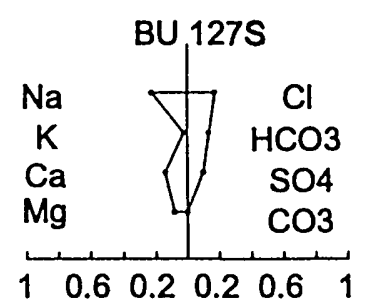

Milliequivalents per liter

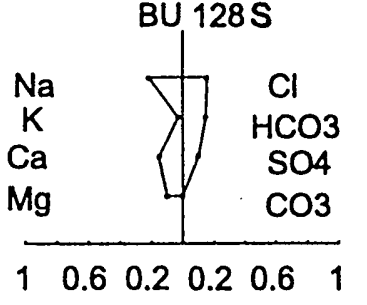

Milliequivalents per liter
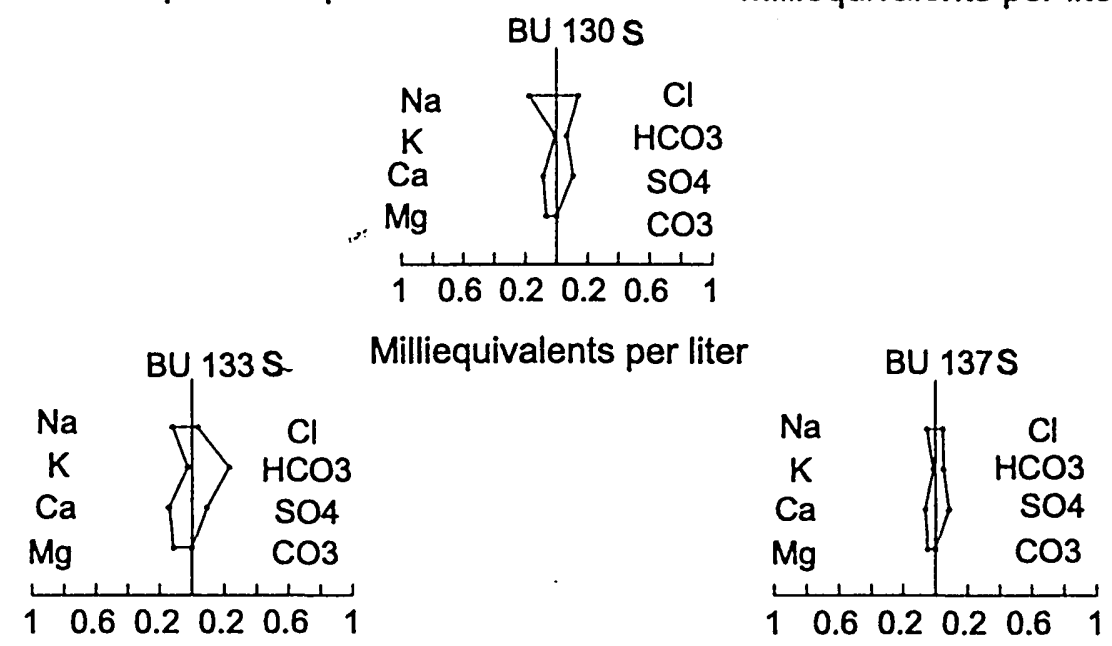

Milliequivalents per liter

Milliequivalents per liter

Figure 10. Analysis of ion concentration represented by patterns based on milliequivalents per liter in ground-water samples, Nepaug Reservoir watershed, northwestern Connecticut, August through September 1999. 


\section{SUMMARY AND CONCLUSIONS}

In 1997, the U.S. Geological Survey (USGS) and the Metropolitan District Commission (MDC) began a cooperative three-phase study to evaluate potential effects of sand and gravel mining on the quality of water entering the Nepaug Reservoir in northwestern Connecticut. The first phase of the study characterized the hydrogeologic framework of the sand and gravel deposits (Stone and others, 2001). Phase 2 of the study (this report) involved additional data collection and interpretation of ground-water level and ground-waterquality data. Phase 3 of the study will focus on surfacewater quality, including estimates of nutrient loads to the Nepaug Reservoir from the watershed.

Ground-water levels were measured, waterquality samples were collected, and hydraulic (slug) tests were conducted in monitoring wells from 1998 through 2000 in the Nepaug Reservoir watershed. Typical seasonal water-level fluctuations in Connecticut were observed in the two areas of thick unconsolidated glacial deposits-referred to as the North Area and the South Area-but the fluctuations were not in phase with each other. Water levels in wells in the South Area responded immediately to the intense precipitation from Tropical Storm Floyd (about 8.5 inches (in.) of rain over 2 days), whereas water levels in wells in the North Area did not show an abrupt rise. Ground-water-level fluctuations ranged from 1.05 $\mathrm{ft}$ to $9.87 \mathrm{feet}(\mathrm{ft})$. Upward head gradients from the deep wells to the shallow wells, indicating discharge zones, were observed at well pairs BU-127D/BU-128S and BU-129D/BU-130S. A downward head gradient, indicating an area of recharge, was observed at well pair BU-140D/BU-141S. All other well pair sites showed little if any vertical head gradients.

Hydraulic (slug) tests were conducted in seven monitoring wells to determine horizontal hydraulic conductivity values of the stratified glacial deposits. Hydraulic conductivity values ranged from 0.93 to 16.7 feet per day (ft/d) and from 1.4 to $23.5 \mathrm{ft} / \mathrm{d}$ using two methods of analysis. These hydraulic conductivity values matched published values for unconsolidated sediments similar to those at the screened interval of the wells.

Water samples were collected from 11 wells to characterize the ground-water quality of the stratified glacial deposits and any seasonal variations in water quality during May 1999 (to represent a ground-water recharge period when water levels are generally high) and during August through September 1999 (to represent a time of little to no recharge when ground-water levels are typically low). Temperature was consistently higher in the late summer samples than in the spring samples in all wells. Dissolved oxygen, sulfate, and silica were the only measured constituents that showed a consistent seasonal pattern. Because of the limited sampling done in this study, a definitive relation between the thickness of the unsaturated deposits and ground-water quality could not be established.

Continued monitoring of streamflow, groundwater levels, and quality of ground and surface water could provide additional information that can be used to determine effects of activities in the watershed. Removal of sand and gravel deposits may affect water quality in and near the reservoir and the physical response of the watershed to precipitation. Groundwater levels and streamflow characteristics show that thick unsaturated deposits of sand and gravel can store significant quantities of water. Sand and gravel mining reduces the thickness of the deposits, and the hydrologic characteristics of a mined area will be similar to areas of thin, but unmined, sand and gravel. Areas of thin unsaturated coarse-grained stratified glacial deposits produce more runoff more quickly than areas of thick unsaturated deposits. A potential consequence of mining, then, would be increased streamflow following precipitation (with more erosive potential) and decreased summer flow. Additional evidence in the scientific literature indicates that thick unsaturated deposits may change the chemistry of infiltrating water. Although data collected in this study were not conclusive, the sampling data indicate that removal of the stratified deposits may result in lower $\mathrm{pH}$ values.

The evidence presented in this report is not definitive with regard to the consequences of mining the glacial deposits in this area; however, the data indicate that thick coarse-grained deposits of sand and gravel have the capacity to store rainfall and release that water slowly to streams, thus decreasing high streamflows and increasing low streamflows. The data also indicate that peaks in ground-water levels related to seasonal fluctuations occur later (in the year) with increasing thicknesses of coarse-grained unsaturated deposits. Mining sand and gravel in the Nepaug Reservoir watershed would reduce the hydrologic buffer provided by thick, unsaturated stratified glacial deposits. 


\section{REFERENCES CITED}

Bouwer, Herman, and Rice, R.C., 1976, A slug test for determining hydraulic conductivity of unconfined aquifers with completely or partially penetrating wells: Water Resources Research, v. 12, no. 3, p. 423-428.

Cooper, H.H., Jr., Bredehoeft, J.D., and Papadopulos, I.S., 1967, Response of a finite-diameter well to an instantaneous charge of water: Water Resources Research, v. 3, no. 1, p. 263-269.

Davies, B.S., 3rd, Morrison, Jonathan, Norris, J.R., and Organek, J.A., 1999, Water resources data, Connecticut, water year 1998: U.S. Geological Survey WaterData Report 98-1, 340 p.

Fetter, C.W., 2001, Contaminant hydrogeology: New York, Macmillan Publishing, $458 \mathrm{p}$.

Handman, E.H., Haeni, F.P., and Thomas, M.P., 1986, Water resources inventory of Connecticut, part 9, Farmington River basin: Connecticut Water Resources Bulletin 29, $91 \mathrm{p}$.

Lapham,W.W., Wilde, F.D., and Koterba, M.T., 1997, Guidelines and standard procedures for studies of ground-water quality - Selection and installation of wells and supporting documentation: U.S. Geological Survey Water-Resources Investigations Report 964233, 110 p.

Likens, G.E., and Bormann, F.H., 1995, Biogeochemistry of a forested ecosystem ( $2 \mathrm{~d}$ ed.): New York, Springer-Verlag, $159 \mathrm{p}$.

National Atmospheric Deposition Program, 2000, National Atmospheric Deposition Program 1999 annual summary: Champaign, Illinois, Illinois State Water Survey, NADP Data Report 2000-02, 16 p.
Radtke, D.B., and Wilde, F.D., eds., 1998, National field manual for collection of water-quality data-Field measurements: U.S. Geological Survey Techniques of Water-Resources Investigations, book 9, chap. A6, unpaginated.

Ranzau, C.E., Jr., Davies, B.S. 3rd, Frick, T.W., and Organek, J.A., 2001, Water resources data, Connecticut, water year 2000: U.S. Geological Survey Water Resources Data Report CT-00, 333 p.

Ranzau, C.E., Jr., Frick, T.W., Norris, J.R., and Martin, J.W., 2000, Water resources data, Connecticut, water year 1999: U.S. Geological Survey Water Resources Data Report CT-99-1, $351 \mathrm{p}$.

Starn, J.J., Stone, J.R., and Mullaney, J.R., 2000, Delineation and analysis of uncertainty of contributing areas to wells at the Southbury Training School, Southbury, Connecticut: U.S. Geological Survey Water-Resources Investigations Report 00-4158, 53 p.

Stone, J.R., Schafer, J.P., London, E.H., and Thompson, W.B., 1992, Surficial materials map of Connecticut: U.S. Geological Special Map, 2 sheets, scale 1:125,000.

Stone, J.R., Starn, J.J., and Morrison, Jonathan, 2001, Hydrogeology of sand and gravel deposits near the Nepaug Reservoir, New Hartford and Burlington, Connecticut: U.S. Geological Survey Water-Resources Investigations Report 01-4059, 38 p.

Wilde, F.D., Radtke, D.B., Gibs, Jacob, and Iwatsubo, R.T., 1999, National field manual for the collection of water quality data-Processing of water samples: U.S. Geological Survey Techniques of Water-Resources Investigations, book 9, chap. A5, 149 p. 


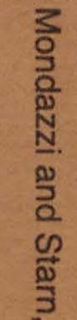

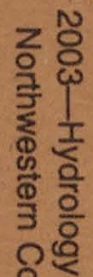

害

气ิ ฐ

$\overrightarrow{0}$

@

임

달

(1)

응 을

을

ฏ

듕.

造 5

낌

궁

్ㅣㅇ్ㅀ

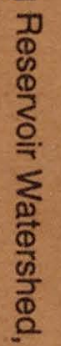

